\title{
SEIS OBJEÇÕES AO DIREITO CIVIL CONSTITUCIONAL
}

\author{
SIX OBJECTIONS TO THE \\ CONSTITUTIONALIZATION OF PRIVATE LAW
}

FERNANDO LEAL ${ }^{1}$

\begin{abstract}
RESUMO: Após uma reconstrução dos diferentes sentidos da expressão "direito civil constitucional", são formuladas seis objeções ao movimento. São elas: o aumento potencial de casos difíceis, a carência metodológica, a banalização da dignidade humana, o excesso de paternalismo judicial, o desequilíbrio institucional causado pela onipotência judicial e os riscos de uma plena sobreposição entre os raciocínios jurídico e moral. Os problemas se referem especialmente às pretensões normativas do direito civil constitucional e realçam a importância do trabalho dogmático para que a reorientação do direito civil em determinadas visões sobre a Constituição e concepções sobre a tomada de decisão jurídica não leve apenas a incerteza, banalização da Constituição e instabilidade institucional. PALAVRAS-CHAVE: Direito Civil Constitucional; Incerteza; Dignidade Humana; Instrumentalismo; Instabilidade Institucional; Onipotência Judicial.
\end{abstract}

ABSTRACT: After reconstructing the different meanings of the so-called "constitutionalization of private law" movement ("direito civil constitucional"), six objections are formulated against it. They are: the potential expansion of hard cases in private law, the methodological deficit of its claims, the trivialization of human dignity, the increase in judicial paternalism, the institutional imbalance caused by judicial omnipotence and the risks of a complete overlap between legal and moral reasoning. The six problems focus on the normative ambitions of the movement and highlight the relevance of further works on legal dogmatics, so that the reorientation of private law in some constitutional views and in some conceptions on legal reasoning doesn't lead merely to uncertainty, trivialization of the Constitution and institutional instability.

KEYWORDS: Constitutionalization of Private Law; Uncertainty; Human Dignity; Instrumentalism; Institutional Instability; Judicial Omnipotence.

\footnotetext{
Artigo recebido em 06.10.2015. Pareceres emitidos em 13.10.2015 e 12.11.2015.

Artigo aceito para publicação em 16.01.2016.

${ }^{1}$ Professor da Escola de Direito da Fundação Getulio Vargas no Rio de Janeiro - RJ. Agradeço, pelos comentários e sugestões a versões anteriores deste artigo, a Gustavo Kloh Muller Neves e Pedro Aleixo.fernando.leal@fgv.br
} 
SUMÁRIO: Introdução; I. A Doutrina Civil Constitucional; 1. Bases Fundamentais; 1.1 A Dimensão Descritiva da Teoria; 1.2 O Direito Civil Constitucional como Teoria Normativa; 2. Sentidos da Expressão; II. As Seis Objeções; 1. O Aumento de Casos Difíceis; 2. A Carência Metodológica; 3. A Trivialização da Dignidade Humana; 4. Excesso de Paternalismo Estatal; 5. O Problema Institucional: afinal, as determinações legislativas vinculam?; 6. A Expansão dos Limites do Direito: por que separar o raciocínio jurídico do raciocínio moral?; Conclusão: funcionalismo ou instrumentalismo?; Referências.

SUMMARY: Introduction; I. The So-called "constitutionalization of private law" movement ("direito civil constitucional"); 1. Foundations; 1.1 The Descriptive Dimension of the Theory; 1.2 The "constitutionalization of private law" movement qua Normative Theory; 2 . Meanings; II. The Six Objections; 1 . The Increase in Judicial Paternalism; 2. The Methodological Deficit; 3. The Trivialization of Human Dignity; 4 . The Increase in Judicial Paternalism; 5 . The Institutional Challenge: can legislative commands after all bind?; 6 . The Distension of the Limits of Law: why disconnect moral reasoning from legal reasoning?; Conclusion: functionalism or instrumentalism?; References.

\section{INTRODUÇÃO}

O direito civil constitucional é inegavelmente um movimento bem sucedido no país. Ainda que os seus reflexos possam ser sentidos com intensidades diferentes pelos estados da federação, o fato é que a influência do discurso civil constitucional se faz notar na doutrina e jurisprudência pátrias em ritmo crescente desde a sua introdução no cenário acadêmico nacional há mais de vinte anos. ${ }^{2}$ O sucesso do movimento pode ser atribuído a uma mistura de abrangente base teórica, interdisciplinaridade, pretensas inovações tanto no plano da metodologia de justificação de decisões jurídicas como no nível da compreensão da estrutura do ordenamento jurídico e um claro ar, ao mesmo tempo, progressista e humanizador. Conjugados, esses apelos encontraram nas últimas décadas um terreno fértil para florescer, seja por um descompasso evidente entre alguns compromissos fundamentais da ordem constitucional pós-88 e as bases sobre as quais o direito civil tradicionalmente se sustentava ${ }^{3}$,

\footnotetext{
${ }^{2}$ Para Gustavo Tepedino, "[o] percurso da doutrina do direito civil [constitucional] brasileiro encontra-se intimamente relacionado ao advento da Assembleia Constituinte, instalada em 1987, e ao clima de engajamento político que marcou o período de redemocratização do Brasil". V. Tepedino, O Direito Civil Constitucional e suas Perspectivas Atuais, p. 356. Um texto do mesmo autor considerado seminal para a formação da doutrina civil constitucional é fruto de uma aula inaugural proferida em 1992 na Faculdade de Direito da UERJ. Cf. Tepedino, Premissas Metodológicas para a Constitucionalização do Direito Civil. Para Paulo Lôbo, por sua vez, tratando de tema diferente, mas ainda relacionado ao direito civil constitucional, "[a] constitucionalização do direito civil, no Brasil, é fenômeno proveniente da migração de princípios fundamentais de direito civil para a Constituição, desde 1934". V. Lôbo, Novas Perspectivas da Constitucionalização do Direito Civil, p. 1.

${ }^{3}$ Por todos, Tepedino, Premissas Metodológicas para a Constitucionalização do Direito Civil, p. 1-2, 13. É importante destacar que mesmo a promulgação do CC/2002 não alterou o avanço do movimento. V. nesse sentido, Lôbo, Novas Perspectivas da Constitucionalização do Direito civil, p. 1.
} 
seja pela construção, em larga medida exitosa, de uma "vontade constitucional"4 por movimentos como o autoproclamado "constitucionalismo brasileiro da efetividade". ${ }^{5}$ Em meio a tantos processos recentes de constitucionalização de diversas áreas do direito, a simbiose entre direito civil e direito constitucional parece ser o produto mais consolidado da afirmação da supremacia e da normatividade constitucionais, a ponto de se poder afirmar que, hoje em dia, diversas teses defendidas por autores do movimento civil constitucional soam como triviais. ${ }^{6}$

O reconhecimento do papel de destaque conquistado pela doutrina civil constitucional não a blinda, porém, de possíveis objeções. Embora, como dito, alguns de seus aspectos sejam atualmente considerados tão triviais que não faz sentido questioná-los (como a necessidade de se considerar os comandos constitucionais para o desenvolvimento de qualquer trabalho dogmático sobre institutos regulados no Código Civil e na Constituição), outras teses do movimento civil constitucional não são tão óbvias. E porque não são óbvias, estão mais facilmente sujeitas a críticas. Neste trabalho, desenvolverei, sem qualquer pretensão de exaustividade, seis objeções que me parecem atingir o alvo quando a doutrina civil constitucional brasileira é colocada sobre a mesa. Tentarei apontar problemas de ordem teórica, metodológica, pragmática, institucional e conceitual contra algumas visões difundidas entre os seus defensores. As críticas serão articuladas tomando como base aspectos de teoria do direito e direito constitucional, e não problemas que podem decorrer dos efeitos, para o próprio direito civil, da sua colonização pelo direito constitucional. ${ }^{7}$ Por meio desses seis pontos pretendo, sobretudo, propor uma discussão a respeito de certas teses que, a despeito de parecerem estabelecidas, são altamente problemáticas. Antes de desenvolver cada ponto, porém, começarei propondo uma reconstrução das principais bases do movimento.

\footnotetext{
${ }^{4}$ A referência quase imediata, neste caso, é ao trabalho de Hesse, A Força Normativa da Constituição.

${ }^{5}$ Barroso, A Doutrina Brasileira da Efetividade.

${ }^{6}$ A obviedade de certos traços do direito civil constitucional - como a inescapável influência da Constituição sobre o direito civil - pode, no limite, tornar "direito civil constitucional" até uma expressão sem sentido. Nesse sentido, argumenta Virgílio Afonso da Silva que "falar em direito civil constitucional pressupõe, a meu ver equivocadamente, que haja uma parte do direito civil completamente imune às influências dos princípios constitucionais e outra que seria por eles conformada. Se, ao contrário, é todo o direito civil que recebe essa influência e não apenas uma parte, a ideia de um direito civil constitucional perde ainda mais sentido, a não ser que a expressão direito civil, sem qualificativos, seja abandonada, por deixar de fazer sentido". V. Afonso da Silva, A Constitucionalização do Direito, p. 172.

${ }^{7}$ Exemplos possíveis desses problemas podem ser notados quando se argumenta que a dogmática do direito civil pode perder a sua autonomia, a estabilidade do direito civil poderia ser abalada pelos aspectos político-institucionais típicos do direito constitucional ou que a autonomia privada poderia ser asfixiada em razão do controle axiológico proposto pelo movimento. Sobre o tema v. Barroso, Neoconstitucionalismo e Constitucionalização do Direito, p. 34, nota 81, e Lôbo, Novas Perspectivas da Constitucionalização do Direito Civil, p. 4.
} 


\section{A DOUTRINA CIVIL CONSTITUCIONAL}

\section{Bases Fundamentais}

Não é raro encontrar aplicações da expressão direito civil constitucional para designar ideias distintas ou um conjunto de ideias que não estão em relação de mútua implicação ou dependência. Ao mesmo tempo é possível distinguir aplicações da expressão com sentidos descritivo, normativo e ideológico, tal qual ocorre com outros rótulos gerais o suficiente (e às vezes provisórios) para abranger uma série de teses que formam um conjunto de proposições nem sempre totalmente coerente. Este é, por exemplo, o caso da expressão "neoconstitucionalismo". ${ }^{8}$ Assim, tanto direito civil constitucional como neoconstitucionalismo funcionam como atalhos verbais para um leque muito amplo de propostas a respeito de como, para os seus seguidores, compreender os processos de teorização e aplicação, respectivamente, do direito civil e do direito constitucional levados adiante, sobretudo, a partir da segunda metade do século $X X$.

Nesse quadro, embora também seja possível entender a doutrina civil constitucional como fruto de uma ideologia' ${ }^{9}$, serão privilegiados os aspectos descritivo e normativo relacionados à expressão com vistas a apresentar as bases fundamentais sobre as quais a necessidade de uma leitura constitucional de todo o direito privado se sustenta.

\subsection{A Dimensão Descritiva da Teoria}

No caso do direito civil constitucional, o sentido descritivo da expressão está relacionado ao conjunto de transformações pelas quais o direito civil e o direito constitucional passaram ao longo do século XX. O direito civil constitucional, neste plano, é retratado como um fato, cujo processo de estabelecimento é quase sempre apresentado como o produto da conjugação de dois grandes movimentos: de um lado, um movimento de retração ou de perda de protagonismo do Código Civil no âmbito do direito privado e no próprio ordenamento jurídico; de outro, um movimento de ascensão ou aumento de importância das Constituições nas ordens jurídicas das democracias ocidentais contemporâneas.

No primeiro caso, o Código Civil, outrora considerado como "a Constituição do direito privado" ${ }^{10}$, passa a perder a sua centralidade ao longo do século XX em razão de ações estatais mais intervencionistas - especialmente no campo econômico -, dos movimentos de dirigismo contratual e da criação de leis especiais para lidar com situações jurídicas específicas que exigiam a tutela

\footnotetext{
${ }^{8}$ V. Sanchís, Neoconstitucionalismo y Ponderación Judicial, p. 123.

${ }^{9} \mathrm{Em}$ um sentido ideológico, o direito civil constitucional pode ser visto como a expressão de compromissos com valores não patrimoniais, especialmente com a dignidade humana, e com a justiça social. Em favor da visão de que a constitucionalização do direito civil tem um caráter ideológico v., endossando palavras de Luiz Edson Fachin, Lôbo, Novas Perspectivas da Constitucionalização do Direito Civil, p. 11.

${ }^{10}$ Tepedino, Premissas Metodológicas para a Constitucionalização do Direito Civil, p. 2.
} 
estatal, mas que não eram contempladas no Código Civil (no caso brasileiro, basta pensar nas leis que regulam temas como locação, relações de consumo, proteção ao idoso, criança e adolescente, todas sustentadas sobre compromissos normativos diversos do voluntarismo, individualismo e patrimonialismo sobre os quais a dogmática tradicional da "Era das Codificações" foi construída). ${ }^{11}$ Com isso, não só o direito público vai ocupando espaços anteriormente considerados de exclusiva abrangência do direito privado, como o Código Civil vai adquirindo "uma função meramente residual, aplicável tão-somente em relação às matérias não reguladas pelas leis especiais". ${ }^{12}$

Ao mesmo tempo, a expressão pressupõe um avanço gradativo de relevância das Constituições. Estas, de um ponto de vista estrutural, não só passam a ocupar o ápice da ordem jurídica e, de um ponto de vista normativo, a ser reconhecidas como documentos dotados de imperatividade, como se tornam os repositórios das principais aspirações da comunidade e de uma série de programas que pretendem condicionar a atuação dos poderes constituídos. Especificamente em relação a esse último traço, o robustecimento temático das Constituições inclui não apenas um farto catálogo de direitos, o estabelecimento de estados de coisas a serem realizados pelos seus destinatários e uma pluralidade de valores fundamentais, mas também temas típicos de direito privado. Além disso, entre outros aspectos, as ambições constitucionais textualmente apreensíveis se tornam referências para o desenvolvimento de teorias e construções dogmáticas (especialmente no âmbito dos direitos fundamentais) capazes de permitir a irradiação dos comandos (ou valores) constitucionais por outras áreas do direito. Juntos, ambos os movimentos de perda de importância do Código Civil e de consolidação do protagonismo constitucional moldaram um cenário em que a leitura do direito civil a partir da Constituição por juristas e tomadores de decisão se torna um fato facilmente constatável em diversos países. ${ }^{13}$

\footnotetext{
${ }^{11}$ Referindo-se a esse processo como de decodificação, v. Fachin, A Reforma no Direito Brasileiro: novas notas sobre um velho debate no direito civil, p. 231. Contra a visão de que essas leis poderiam estatuir microssistemas, v. Tepedino, $O$ Direito Civil Constitucional e suas Perspectivas Atuais, p. 363. Para o autor, a expressão poderia levar à falsa percepção de fragmentação do sistema jurídico. A convivência de diversos sistemas dentro do sistema jurídico seria uma visão de fundamentação ilusória porque, para Tepedino, o ordenamento jurídico é unitário e essa unidade é garantida pelos valores constitucionais.

${ }^{12}$ Tepedino, Premissas Metodológicas para a Constitucionalização do Direito Civil, p. 12.

${ }^{13}$ Não se pode negligenciar que nem sempre os processos históricos que levaram à afirmação de movimentos de conformidade constitucional do direito civil são os mesmos. Se no caso brasileiro o problema factual que impulsionou o avanço do direito civil constitucional foi o descompasso entre o Código de 1916, marcadamente de inspiração liberal, e os compromissos sociais da Constituição federal de 1988, no caso italiano, como ressalta Perlingieri, o problema a ser superado era o de tensão entre um Código Civil de 1942, inspirado em uma lógica produtivista, baseada no interesse do legislador de "potencializar o Estado, aumentar a produtividade, fazendo do produtivismo a característica precípua do ordenamento" - como aponta o autor - e uma Constituição alicerçada sobre o respeito aos direitos fundamentais da pessoa humana. V. Perlingieri, Perfis do Direito Civil, p. 4.
} 


\subsection{O Direito Civil Constitucional como Teoria Normativa}

Do ponto de vista normativo, o direito civil constitucional pode ser compreendido como uma proposta teórica que pretende justificar a preferência por um modelo em que a teorização e a aplicação do direito civil devem passar necessariamente pelo filtro da Constituição. Tomando sempre o caso brasileiro como referência, creio que esse modelo se sustenta essencialmente sobre cinco pilares.

Em primeiro lugar, o direito civil constitucional endossa uma teoria da Constituição. Essa teoria se assenta sobre a afirmação da supremacia e da normatividade da Constituição, a centralidade dos direitos fundamentais como sistema de referência da ordem constitucional, a concepção de que as Constituições encarnam os valores ético-políticos fundamentais da comunidade que pretende reger ${ }^{14}$ e o reconhecimento de que os comandos constitucionais e os compromissos valorativos assumidos pelo constituinte funcionam fundamentalmente como limites e programas que condicionam a atuação de atores públicos e privados, na medida em que é a Constituição e, no seu centro, a sua "tábua axiológica", que garantem a unidade do ordenamento jurídico. ${ }^{15}$

Em segundo lugar, a doutrina parte de uma teoria sobre a eficácia dos direitos fundamentais. Neste caso, entra em cena a dimensão objetiva dos direitos fundamentais e, como seus corolários, o reconhecimento de que a esses direitos é possível vincular uma eficácia irradiante e uma eficácia horizontal. Dessas eficácias se extraem basicamente as ideias de que, respectivamente, o sistema de direitos fundamentais se espraia por todo o ordenamento, condicionando a compreensão e a aplicação do direito vigente, inclusive do direito privado ${ }^{16}$, e que os direitos fundamentais não só garantem posições jurídicas contra o Estado, mas também se aplicam nas relações entre particulares. ${ }^{17}$

Em terceiro lugar, o direito civil constitucional incorpora uma teoria da norma jurídica e uma teoria da tomada de decisão jurídica, notadamente da decisão judicial. No primeiro caso, a doutrina civil constitucional ecoa o discurso - incorporado primeiro por constitucionalistas - de que princípios são

\footnotetext{
${ }^{14}$ Para Perlingieri "[n]o centro dos sistemas jurídicos contemporâneos dos documentos jurídicos, como são as constituições, que contém princípios éticos, estas devem ser evolutivamente interpretadas de acordo com a modificação dos valores ético-políticos da comunidade a que a Constituição se refere". V. Perlingieri, A Doutrina do Direito Civil na Legalidade Constitucional, p. 5. A aproximação, ainda que imperfeita, é certamente com a concepção da Constituição como "ordem objetiva de valores" afirmada pelo Tribunal Constitucional Federal alemão na decisão do famoso caso Lüth.

${ }^{15}$ Assim Perlingieri, Perfis do Direito Civil, p. 4-5. Tepedino, O Direito Civil Constitucional e suas Perspectivas Atuais, p. 361-362. Tepedino, Premissas Metodológicas para a Constitucionalização do Direito Civil, p. 7. Esses elementos podem ser encontrados no que Luis Roberto Barroso chama de marco teórico do neoconstitucionalismo. V. Barroso, Neoconstitucionalismo e Constitucionalização do Direito, p. 6 e ss. V. também Sarmento, Direitos Fundamentais e Relações Privadas, parte I, cap. II.

${ }^{16}$ Sarmento, Direitos Fundamentais e Relações Privadas, p. 154 e ss.

${ }^{17}$ Barroso, Neoconstitucionalismo e Constitucionalização do Direito, p. 34-35.
} 
espécies do gênero "norma jurídica". Para que a almejada efetividade constitucional pudesse atingir o direito civil e criar, assim, as bases para uma doutrina da conformação constitucional do direito infraconstitucional, era necessário que os compromissos fundamentais da Constituição - ideias nem sempre de conteúdo preciso ou unívoco como dignidade humana, democracia, solidariedade social, igualdade e justiça - não fossem considerados meros elementos colmatadores de lacunas, como os "princípios gerais de direito" referidos no artigo $4^{\circ}$ da Lei de Introdução às Normas de Direito Brasileiro, ou exortações políticas não vinculantes. Eles deveriam, ao contrário, ser concebidos como normas capazes de interferir em processos de criação e aplicação judicial do direito, independentemente de concretização legislativa. ${ }^{18}$ No segundo caso, o movimento civil constitucional sugere "uma teoria da interpretação jurídica que não seja formalística - fundamentada no mecanismo lógico-teórico da subsunção do fato concreto à norma abstrata - [mas uma] que saiba propor uma interpretação das disposições normativas no que se refere à hierarquia das fontes e dos valores, em uma acepção necessariamente sistemática e axiológica". ${ }^{19}$ Dessa orientação fundamental, a doutrina civil constitucional chega a uma teoria holística e, assim, particularista do raciocínio jurídico. Isso porque se exige não só a consideração, em cada caso concreto, de todos os elementos factuais e normativos incidentes - independentemente da presença, entre aqueles elementos, de uma regra claramente aplicável -, como também que o intérprete busque sempre definir a norma do caso concreto em conformidade com os princípios e os valores do ordenamento. ${ }^{20}$ Para tanto, o intérprete deve atentar para "os critérios hermenêuticos inovadores, como a ponderação dos interesses e dos valores, da razoabilidade, da proporcionalidade, da adequação, da subsidiariedade, recuperando a facticidade para a juridicidade". ${ }^{21}$ Segundo Tepedino, "esta técnica hermenêutica mostra-se como a única capaz de fazer prevalecer os valores do ordenamento em cada decisão judicial."22

Em quarto lugar, o movimento civil constitucional assume um compromisso valorativo explícito com a realização da dignidade humana, considerado o princípio fundamental e, para alguns, absoluto ${ }^{23}$ da ordem constitucional e, por conseguinte, da própria ordem jurídica. Nas palavras de Bodin de Moraes, a Constituição federal proclamou a dignidade "entre os princípios fundamentais, atribuindo-lhe o valor supremo de alicerce da ordem jurídica democrática". ${ }^{24}$ É este compromisso que justifica uma leitura funcionalista das situações

\footnotetext{
${ }^{18}$ Assim Tepedino, Premissas Metodológicas para a Constitucionalização do Direito Civil, p. 18. V. também Perlingieri, A Doutrina do Direito Civil na Legalidade Constitucional, p. 1-2.

${ }^{19}$ Perlingieri, A Doutrina do Direito Civil Constitucional, p. 3.

${ }^{20}$ V. Tepedino, O Direito Civil Constitucional e suas Perspectivas Atuais, p. 361 e Perlingieri, A Doutrina do Direito Civil Constitucional, p. 3.

${ }^{21}$ Perlingieri, A Doutrina do Direito Civil na Legalidade Constitucional, p. 4.

${ }^{22}$ Tepedino, O Direito Civil Constitucional e suas Perspectivas Atuais, p. 361.

${ }^{23}$ Moraes, Danos à Pessoa Humana, p. 85.

${ }^{24}$ Moraes, Danos à Pessoa Humana, p. 83.
} 
jurídicas patrimoniais, que passam a estar a serviço de valores existenciais. Afinal, "[a] pessoa humana é o centro do ordenamento, impondo-se assim tratamento diferenciado entre os interesses patrimoniais e existenciais". ${ }^{25}$

Finalmente, em quinto lugar, a doutrina civil constitucional pressupõe uma determinada concepção sobre a estrutura do sistema jurídico, assentada sobre a centralidade da Constituição, a abertura, a pluralidade de fontes e a unidade. Nos dois primeiros casos, como já afirmado, coloca-se a Constituição como o centro do ordenamento e os seus princípios fundamentais como os garantidores da ordem e unidade que conferem caráter sistemático ao conjunto de elementos que compõem o direito de uma dada comunidade. ${ }^{26}$ No terceiro aspecto, concebe-se o sistema jurídico como composto por uma pluralidade de fontes normativas ${ }^{27}$ e marcado pela abertura "a múltiplos matizes culturais, informados por valores historicamente determinados, presentes no seio social". ${ }^{28} \mathrm{Em}$ relação ao quarto ponto, como uma espécie de produto dos demais pilares sobre os quais se constrói o movimento, o sistema jurídico deixa de se estruturar em torno da grande dicotomia entre o público e o privado, que se torna sem sentido a partir do momento em que se consolida a centralidade constitucional. ${ }^{29}$

São esses cinco pilares que, segundo os defensores da perspectiva civil constitucional, criam as condições não só para a refundação de conceitos (v.g. direito subjetivo) e institutos clássicos de direito civil (v.g. família, propriedade e contrato), como para o desenvolvimento de uma teoria funcionalista do direito privado, que, sobretudo, reorienta todos os institutos de direito civil - em especial as situações patrimoniais - para o reconhecimento, a afirmação e a proteção de situações subjetivas existenciais. ${ }^{30}$

\section{Sentidos da Expressão}

Até este momento, vimos que o direito civil constitucional é substancialmente uma teoria jurídica funcionalista que se apresenta tanto como um produto jurídico factual de diversos movimentos históricos, políticos e sociais ocorridos ao longo do século $\mathrm{XX}$, como uma doutrina normativa abrangente que ergue pretensões de determinar como o direito civil deve ser compreendido e aplicado. A partir desses traços, é possível definir cinco sentidos diferentes relacionados à expressão. Assim, "direito civil constitucional" pode se referir (i) ao processo de absorção, pelas Constituições, de temas tipicamente regulados

\footnotetext{
${ }^{25}$ Tepedino, O Direito Civil Constitucional e suas Perspectivas Atuais, p. 365.

${ }^{26}$ Perlingieri, A Doutrina do Direito Civil na Legalidade Constitucional, p. 2.

${ }^{27}$ Tepedino, O Direito Civil Constitucional e suas Perspectivas Atuais, p. 362: "[...] o ordenamento não se resume ao direito positivo, mas abrange todos os vetores de influência da sociedade".

${ }^{28}$ Tepedino, O Direito Civil Constitucional e suas Perspectivas Atuais, p. 363.

${ }^{29}$ Tepedino, Premissas Metodológicas para a Constitucionalização do Direito Civil, p. 19. Para um olhar crítico sobre a distinção entre direito público e direito privado v. Afonso da Silva, A Constitucionalização do Direito, p. 172-174.

${ }^{30}$ Assim, Tepedino, O Direito Civil Constitucional e suas Perspectivas Atuais, p. 365, para quem "as situações patrimoniais devem ser funcionalizadas às existenciais".
} 
pelo Código $\mathrm{Civil}^{31}$, (ii) à necessidade de orientação dos processos de criação estatal do direito e de obrigações entre particulares nos valores constitucionais, (iii) à valorização da pessoa humana como centro da ordem jurídica e parâmetro central para a aferição da legitimidade de ações estatais e de agentes privados e da qualidade do trabalho dogmático desenvolvido no âmbito do direito civil, (iv) à necessidade de os processos de interpretação do direito e, em sentido mais amplo, de definição de obrigações jurídicas concretas pelo Poder Judiciário se orientarem na realização máxima de valores constitucionais fundamentais de caráter não-patrimonial e (v) à possibilidade de aplicação direta de dispositivos constitucionais para a solução de problemas de direito privado. O direito civil constitucional pode ser concebido, portanto, como uma doutrina que se serve de opções explícitas do constituinte e interpretações sobre as preferências da ordem constitucional para explicar e, sobretudo, definir (i) como regras e institutos de direito civil são e devem ser produzidos, compreendidos e aplicados e (ii) como problemas de direito privado são e devem ser solucionados.

As pretensões do movimento são inegavelmente altas. As peças que compõem as suas bases de justificação, complexas. A consolidação da doutrina civil constitucional nos últimos anos, contudo, não é suficiente para impedir que se possa fazer um balanço crítico a respeito da consistência das suas principais teses e dos efeitos práticos e teóricos produzidos pela sua ampla aplicação. Contudo, é certo que a ampla aceitação de um discurso comprometido com valores tão caros à Constituição e convergente com aquilo que se tornou entre nós a maior expressão da vanguarda e da sofisticação da teoria constitucional e da metodologia jurídica torna a tarefa de apontar possíveis problemas do movimento civil constitucional, em alguma medida, árdua. Os ônus de justificação a serem superados por quem formula críticas são, nesse contexto, reforçados. Sem negligenciar esse aspecto, e visando a trazer argumentos para uma apreciação crítica e não ideologicamente carregada do direito civil constitucional, passa-se a se desenvolver as seis críticas ao movimento.

\section{AS SEIS OBJEÇÕES}

\section{O Aumento de Casos Difíceis}

Para o direito civil constitucional, a concretização da Constituição é uma tarefa que se efetiva em cada caso. O controle da conformidade constitucional, com outras palavras, dá-se em situações específicas, nas quais há de se privilegiar a solução "coerente, adequada e razoável e então correspondente à tábua dos valores normativamente relevantes, presentes na Constituição". ${ }^{32}$

\footnotetext{
${ }^{31}$ Paulo Lôbo, como já citado, refere-se a um "processo de elevação ao plano constitucional dos princípios fundamentais do direito civil". V. Lôbo, Novas Perspectivas da Constitucionalização do Direito Civil, p. 2.

${ }^{32}$ Perlingieri, A Doutrina do Direito Civil na Legalidade Constitucional, p. 4.
} 
Decidir com base em regras contidas em textos legislativos não é, assim, um empreendimento que satisfaz plenamente as diretrizes normativas da teoria da interpretação sugerida pelo direito civil constitucional. Para além da aplicação de regras incidentes em casos concretos, existe um dever permanente de aferição da adequação da resposta fornecida pelas regras com "valores" (na expressão de Perlingieri) ou "princípios" (para dizer com Tepedino) constitucionais, que devem ser sempre considerados. Nessa linha, defende Bodin de Moraes que "mesmo em presença de aparentemente perfeita subsunção a uma norma de um caso concreto, é necessário buscar a justificativa constitucional daquele resultado hermenêutico". ${ }^{33}$

A necessidade de consideração constante de elementos constitucionais nos processos de justificação de decisões, apesar do apelo evidente a supostas vantagens relacionadas à busca pelas melhores soluções para cada caso, à afirmação frequente da superioridade e da centralidade da Constituição e à promoção da efetividade constitucional, conduz a uma teoria da tomada de decisão jurídica bastante problemática, ao conjugar (i) o aumento de variáveis no processo decisório, (ii) escaladas de justificação até os mais rarefeitos compromissos constitucionais e (iii) particularismo decisório, i.e. a visão de que decisões jurídicas devem ser tomadas levando sempre em consideração todas as propriedades relevantes do caso concreto e as normas a ele relacionados. Uma vez implementados, esses três fatores aumentam a complexidade dos processos jurídico-decisórios e contribuem para a diluição das fronteiras entre casos fáceis e difíceis, o que afeta drasticamente a possibilidade de controle das amplas margens de discricionariedade judicial exercidas na solução de problemas pontuais. ${ }^{34}$

O dever permanente de examinar a conformidade constitucional exige que participantes de processos argumentativos dentro do direito manipulem não só a legislação infraconstitucional, como também referenciais vagos da Constituição como "dignidade humana", "função social" e "solidariedade" em busca da suposta solução constitucionalmente adequada para o caso concreto. O aumento de variáveis no processo decisório, selecionadas a partir do dever de consideração de todas as nuances de cada caso, é evidente. Da mesma forma, torna-se claro o aumento dos custos de decisão, i.e. dos custos envolvidos para se chegar à resposta jurídica para o caso sob consideração. ${ }^{35}$ Construir a melhor solução para casos específicos não passa a depender, como já anunciado, apenas da subsunção de fatos aos predicados fáticos de regras, por exemplo, do Código Civil. Ao contrário, questões concretas de direito civil são vistas, na verdade, como oportunidades para o empreendimento de esforços de concretização da Constituição, considerados custosos na medida em que exigem do juiz a superação de

\footnotetext{
${ }^{33}$ Moraes, A Caminho de um Direito Civil Constitucional, p. 11.

${ }^{34} \mathrm{O}$ tema será aprofundado no item 5 , infra.

${ }^{35}$ Sunstein, Must Formalism be Defended Empirically?, p. 647.
} 
ônus como os (i) de identificação dos elementos constitucionais incidentes no caso, (ii) de determinação de sentido dos valores ou princípios constitucionais envolvidos e, na hipótese de divergência entre a resposta legislativa e a resposta constitucional fornecidas para o caso, (iii) de harmonização das tensões estruturais e institucionais envolvidas quando há percebido descompasso entre uma regra e um princípio.

No primeiro caso, o que está em jogo é um dever prévio a qualquer tarefa de conformidade constitucional: o de indicação de todos os princípios constitucionais incidentes no caso, sobretudo daqueles que estão em relação de tensão, e não apenas da parte da Constituição que possa ser útil para fazer prevalecer uma resposta com aparência de justificação adequada. Em uma ordem constitucional plural e compromissória como a brasileira, não é raro encontrar compromissos constitucionais com estrutura normativa de princípios em relação não harmônica. Localizar as tensões, em vez de privilegiar miopias constitucionais, é, assim, crucial para a conformidade constitucional. ${ }^{36}$

No segundo caso, o aspecto ainda anterior ao de concretização constitucional é o de delimitação do sentido operacionalizável dos comandos que se pretende aplicar no caso concreto. Evocar simplesmente expressões vagas como "dignidade", "autonomia" ou "melhor interesse da criança" não é suficiente para a busca de respostas constitucionais adequadas para casos específicos, se não há prévio acordo semântico sobre o emprego dessas expressões no caso - e, dinamicamente, na solução de diversos casos. Sem esses acordos, sobram apenas indeterminação e discricionariedade.

Em relação ao terceiro aspecto, finalmente, é preciso considerar, antes de tudo, que o entrincheiramento de razões para agir em regras se justifica em nome de objetivos socialmente relevantes, como igualdade, confiança, eficiência, estabilidade e alocação de poder. ${ }^{37}$ Decidir com base em regras, i.e. acatar como razões suficientes para a tomada de decisão as suas prescrições sem a consideração de demais razões, é, portanto, uma maneira não só de garantir coordenação social, dissolver desacordos morais particulares e possibilitar a execução de planos individuais e coletivos, como é, em larga medida, também uma forma de honrar compromissos constitucionais. Porque a observância de regras se justifica moral e constitucionalmente, tanto a

\footnotetext{
${ }^{36}$ Nesse sentido, um possível problema constitucional do movimento decorre da tentativa de se relacionar à leitura civil constitucional uma narrativa que reduz a importância de compromissos contidos no texto da Constituição que não sugerem uma única resposta para problemas jurídicos concretos e tampouco permitem afirmar que a leitura civil constitucional é a única constitucionalmente adequada à realidade brasileira. $\mathrm{O}$ enfrentamento de uma pergunta como "deve ser despejado o locador inadimplente que não tem onde morar?" deixa claro como olhar apenas para a dignidade humana, o direito social à moradia ou a igualdade material é, desde o início, simplificar um problema mais complexo do ponto de vista constitucional, pois a mesma Constituição que protege aqueles princípios também preserva, por exemplo, o ato jurídico perfeito e o direito de propriedade. Agradeço a Gustavo Kloh por me fazer atentar para este ponto e me fornecer o problema indicado.

${ }^{37}$ V. Schauer, Playing by the Rules, cap. 7. V. também Ávila, Teoria dos Princípios, p. 112-114.
} 
consideração de outros elementos ao lado das prescrições das regras como a sua superação deveriam ser exceções na ordem jurídica ${ }^{38}$, e não incentivadas, como parece propor o direito civil constitucional, que investe em um modelo particularista de tomada de decisão. Mas, uma vez incentivadas, é preciso considerar que conflitos entre regras e princípios não se resolvem apenas hierarquicamente, ou seja, com a simples referência à estatura infraconstitucional da regra e ao status constitucional do princípio. Além de uma simplificação extrema, isso significaria simplesmente desconsiderar as razões que justificam a importância de seguir regras.

Assim, ao contrário do que, por exemplo, afirma Bodin de Moraes, seria preciso haver excelentes razões para a consideração permanente de princípios constitucionais em qualquer caso e para justificar a não aplicação da regra incidente em caso de "perfeita subsunção" de fatos a prescrições infraconstitucionais. Tornar, contudo, o processo de tomada de decisão jurídica um dever de consideração constante de comandos infraconstitucionais e constitucionais sem o fornecimento de um modelo de regras capaz de (i) não só justificar a preferência pelo não entrincheiramento das razões sustentadas por regras e o seu potencial para excluir outras razões, como (ii) de acomodar facilmente soluções que privilegiam com frequência a superação de regras em casos concretos - tarefa, até o ponto em que as minhas pesquisas avançaram, não cumprida pelo direito civil constitucional brasileiro $^{39}$ - contribui apenas para um aumento incontrolável das variáveis decisórias que precisam ser levadas em consideração em cada caso.

Em suas melhores luzes, o que o modelo decisório particularista do direito civil constitucional sugere é que um sem número de razões normativas seja permanentemente levado a sério na solução de cada problema pontual: as regras infraconstitucionais incidentes, suas justificações subjacentes, os princípios que justificam a importância de seguir regras e todos os demais princípios constitucionais relevantes aplicáveis, que nem sempre convergirão para um único resultado, para a construção da melhor resposta constitucional para o caso. Sem métodos de decisão capazes de controlar racionalmente a manipulação de tantas variáveis - se é que tais métodos são possíveis -, o principal risco do amplo endosso desse modelo normativo de tomada de decisão é o da transformação de toda e qualquer questão privada controvertida em um caso difícil. ${ }^{40}$ Isso porque, dado o conjunto de razões que precisa ser considerado, padrões autoritativos de decisão preexistentes à solução do

\footnotetext{
${ }^{38}$ V. Alexy, Theorie der Grundrechte, p. 89. Ávila, Teoria dos Princípios, p. 114. Barcellos, Ponderação, Racionalidade e Atividade Jurisdicional, cap. VIII.

${ }^{39}$ Igualmente possível seria o fornecimento de uma teoria moral holista capaz de justificar por que as partes envolvidas em um caso concreto teriam o direito a obter sempre as melhores respostas para os seus problemas, consideradas todas as circunstâncias e independentemente da presença de padrões autoritativos especificamente aplicáveis ao caso.

${ }^{40}$ Sobre como as relações entre particularismo e escaldas de justificação até a Constituição podem contribuir para o aumento de casos difíceis, v. Leal, Todos os Casos Jurídicos são Difíceis?
} 
caso (basicamente regras e precedentes) não serão considerados suficientes, por si sós, mesmo quando claros, para fornecer respostas para casos concretos (já que existe um dever permanente de conformidade constitucional ${ }^{41}$ ). Além disso, muito provavelmente haverá razões favoráveis e contrárias a qualquer solução sob consideração. Não é surpreendente, neste ponto, notar que essa seja a característica central do que, para Alexy, caracteriza um caso como difícil. $^{42}$

Até este ponto, o direito civil constitucional contribui apenas para a onipresença da Constituição - e de todas as suas questões tormentosas - em cada problema da vida ${ }^{43}$ e o aumento exponencial da incerteza vinculada ao desfecho de casos concretos. No mundo civil constitucional, todos os casos são potencialmente difíceis. E essa dificuldade se aprofunda quando se adiciona ao argumento a tendência do movimento de idealizar a figura do magistrado, que precisa ser compreendido como um ator institucional capaz de conhecer e processar todos aqueles dados para fornecer respostas constitucionalmente adequadas. Nesse sentido, é possível questionar se a busca por traduzir, na solução do caso concreto, a totalidade do ordenamento, complexo e unitário, preserva, de fato, a segurança jurídica, como sugere Tepedino. ${ }^{44}$ A relação entre particularismo e segurança está longe de ser intuitiva. Ao contrário, dados os custos envolvidos no processo de manipulação de diversos elementos normativos, nada leva a crer que se possa inferir facilmente que o aumento da complexidade do processo decisório leve à

\footnotetext{
${ }^{41}$ Mesmo em casos de oferecimento da solução oferecida pela regra, o dever de conformidade constitucional não permitirá que se compreenda que a solução do caso foi determinada pela regra. Ao contrário, se o referido dever exige prévia consideração de princípios constitucionais no caso, a "aplicação" da regra pode ser lida, na verdade, como o resultado da simples constatação de que as normas constitucionais consideradas pelo tomador de decisão fornecem a mesma resposta que a regra pensada pelo legislador. Nesse quadro, não é o texto das regras que "faz o trabalho", mas o resultado da grande "ponderação" realizada pelo juiz após a consideração de todas as variáveis anteriormente indicadas.

${ }^{42}$ Alexy, On Balancing and Subsumption, p. 436. O recurso frequente a princípios constitucionais e a abertura para a consideração de colisões é reconhecido por Maria Celina Bodin de Moraes como uma contribuição para o aumento do número de casos difíceis. Para a autora, "[a] necessidade metodológica de aplicar os princípios constitucionais a todas as relações jurídicas, inclusive as intersubjetivas de natureza privada, fez com que se multiplicassem as ocasiões de colisões de princípios. São tais casos que, por influência do direito norte-americano, passam a formar a categoria dos chamados casos difíceis". V. Moraes, O Princípio da Dignidade Humana, p. 21.

${ }^{43} \mathrm{~A}$ panconstitucionalização incentivada pelo direito civil constitucional tende a aumentar a incerteza de processos jurídicos de tomada de decisão não só pelas referências a comandos vagos e pela proliferação de colisões de princípios, mas também pela internalização, em cada caso, das disputas teóricas substantivas por trás de diferentes visões sobre a Constituição, as relações entre poderes e o papel do magistrado na democracia, que também acabam contribuindo para justificar decisões em diferentes sentidos para problemas concretos que envolvem aspectos constitucionais. Sobre o assunto v. Leal, Ziele und Autorität, p. 277-284.

${ }^{44}$ Tepedino, O Direito Civil Constitucional e suas Perspectivas Atuais, p. 370: "O magistrado, ao solucionar o caso concreto, observa também o Prof. Pietro Perlingieri, traduz a totalidade do ordenamento, complexo e unitário. Cada decisão revela, desta maneira, o ordenamento no caso concreto, preservando-se a segurança jurídica".
} 
promoção de corolários da segurança jurídica. Incentivar o particularismo decisório por meio de princípios pode ser uma maneira de realizar mais efetivamente comandos constitucionais, permitir a realização de objetivos em casos concretos e tornar o processo decisório mais adaptável às circunstâncias. Mas, ainda que não se problematize a real possibilidade de alcance desses objetivos por um modelo decisório baseado em princípios que devem ser concretizados e/ou harmonizados em cada caso concreto, é preciso que um tal modelo seja operacionalizável a ponto de se tornar confiável ao longo do tempo. Sem isso, o direito civil constitucional se resume ao deslumbramento com o discurso dos princípios, cujos efeitos perversos já vêm sendo diagnosticados em outros domínios. ${ }^{45}$

\section{A Carência Metodológica}

O aumento potencial de casos difíceis poderia ser um problema de menor impacto se a doutrina civil constitucional oferecesse métodos de decisão capazes de manter sob controle as incertezas relacionadas à necessidade de manipulação de regras infraconstitucionais e princípios constitucionais na solução de cada caso concreto. Processos de concretização da Constituição ou de harmonização de deveres constitucionais em relação de tensão deveriam, nesse sentido, ser conduzidos por métodos capazes de especificar os ônus de argumentação que devem ser superados nos processos de justificação de juízos normativos singulares e garantir, no mínimo, algum grau de previsibilidade dos resultados e de controle da discricionariedade judicial. Essas são não apenas condições necessárias para a fixação de referenciais para a construção de respostas constitucionalmente adequadas que não dependam exclusivamente de virtudes pessoais de tomadores de decisão, como também são exigências mínimas que, uma vez atendidas, impedem a caracterização de uma determinada metodologia como irracional. ${ }^{46}$

Métodos decisórios capazes de satisfazer exigências fracas de racionalidade como as levantadas não precisam atuar como algoritmos decisórios que conduzem a uma única resposta correta. De fato, como reconhece Perlingieri, "[s]e o direito se funda no processo que consente o seu conhecimento, não é necessário que tal processo assuma a forma da lógica matemática ou simule, de qualquer modo, os procedimentos das ciências naturais (...) para garantir o rigor e o controle público da argumentação do intérprete". ${ }^{47}$ Mas, mesmo tomando por base esse pressuposto, para o direito civil constitucional não só uma teoria da interpretação é desejável como o investimento em instrumentos metodológicos se torna uma necessidade para impedir que as suas propostas

\footnotetext{
${ }^{45}$ V. Ávila, Neoconstitucionalismo: entre a "ciência do direito" e o "direito da ciência", p. 1-19 e Sundfeld, Princípio é Preguiça? , p. 60-84.

${ }^{46}$ Para a visão de que esses elementos impedem que a fórmula do peso proposta por Alexy seja considerada irracional, v. Schauer, Balancing, Subsumption, and the Constraining Role of Legal Text, p. 309-311.

${ }^{47}$ Perlingieri, Perfis do Direito Civil, p. 66.
} 
normativas criem um ambiente de plena insegurança. ${ }^{48}$ Para dizer com Perlingieri, a atividade de interpretação precisa ser uma atividade vinculada, controlada e responsável, ${ }^{49}$ ainda que se escape da subsunção como modelo padrão de aplicação do direito e se afaste a crença ingênua de que métodos decisórios podem controlar completamente a subjetividade do intérprete.

Dada a quantidade de variáveis que tomadores de decisão deveriam levar em consideração para a construção da resposta adequada para um caso concreto, seria possível, antes de tudo, problematizar a viabilidade de métodos capazes de garantir satisfatoriamente o alcance daqueles objetivos quando aplicados por pessoas de carne e osso. Se a aplicação consistente de métodos capazes de garantir níveis aceitáveis de controle da subjetividade do juiz e de previsibilidade das suas respostas depender de condições ideais ou de capacidades sobre-humanas, o problema relevante deixa de ser de falta de racionalidade do método, mas de excesso de racionalidade. ${ }^{50}$ Para que se possa, porém, problematizar as pretensões de racionalidade, em qualquer sentido, de métodos de decisão, é preciso que critérios de interpretação sejam previamente fixados. Sem isso, não há o que se criticar. No caso do direito civil constitucional, as apostas costumam ser feitas em expressões vagas ou métodos já conhecidos, contra os quais já foram formuladas críticas, que, por sua vez, não são enfrentadas pelos autores do movimento. Perlingieri, por exemplo, cita "critérios hermenêuticos inovadores, como a ponderação dos interesses e dos valores, da razoabilidade, da proporcionalidade, da adequação, da subsidiariedade"51 e uma interpretação "necessariamente sistemática e axiológica" ${ }^{\prime 2}$. Mas nada diz sobre o sentido de razoabilidade, o que entende por "ponderação", como operacionalizar a busca adequada por harmonia sistêmica e consideração de objetivos e tampouco enfrenta objeções amplamente dirigidas aos potenciais da proporcionalidade para conduzir processos de tomada de decisão que envolvem princípios em colisão. Na mesma linha, afirma também o autor que o controle da atividade interpretativa está diretamente relacionado a uma motivação idônea e adequada ${ }^{53}$, ainda que não se defina quando uma motivação satisfaz qualquer uma dessas exigências. Tepedino, por sua vez, refere-se à importância da "otimização de princípios" ${ }^{54}$ e menciona a necessidade de "fortalecer e difundir a teoria da argumentação,

\footnotetext{
${ }^{48}$ A consciência da importância de métodos de decisão para controlar a subjetividade judicial pode ser vista em Tepedino, que se refere à definição de um "compromisso metodológico, que pode ser dividido em duas linhas de atuação: (i) há de se dotar de coerência metodológica o processo de decisão judicial; e (ii) há de se procurar a unicidade de critérios interpretativos, a partir de um estudo aprofundado dos princípios, que permita a construção dogmática". V. Tepedino, O Direito Civil Constitucional e suas Perspectivas Atuais, p. 369.

${ }^{49}$ Perlingieri, Perfis do direito civil, p. 81 e s.

${ }^{50}$ Schauer, Balancing, Subsumption, and the Constraining Role of Legal Text, p. 311. V. também Leal, Racional ou Hiper-racional?, p. 186 e ss.

${ }^{51}$ Perlingieri, A Doutrina do Direito Civil na Legalidade Constitucional, p. 4.

52 Perlingieri, A Doutrina do Direito Civil na Legalidade Constitucional, p. 3.

${ }^{53}$ Perlingieri, Perfis do Direito Civil, p. 81.

${ }^{54}$ Tepedino, O Direito Civil Constitucional e suas Perspectivas Atuais, p. 369.
} 
para legitimar o discurso jurídico e a decisão judicial". ${ }^{55}$ Mas nada é dito sobre o sentido de otimização ou sobre como lidar com as objeções levantadas contra a teoria dos princípios de Robert Alexy - a referência mais evidente quando está em jogo a concepção de princípios como mandamentos de otimização. No mesmo sentido, regras formais ou materiais de argumentação não são fornecidas. Assim, o direito civil constitucional passa a depender exclusivamente do trabalho dogmático e de mecanismos de controle da variância das interpretações sustentados sobre a estrutura de organização hierarquizada do Judiciário (como uma prática saudável de precedentes ou um sistema processual que atribua a um órgão de cúpula a competência para uniformizar a jurisprudência ${ }^{56}$ ) para, por meio da reformulação de institutos jurídicos e categoriais tradicionais do direito civil, orientar processos de solução de questões privadas. Em todas essas hipóteses, porém, o direito civil constitucional não traz nenhuma grande inovação em termos de controle da subjetividade judicial.

Seria possível objetar, no entanto, que ao menos a regra da proporcionalidade, provavelmente a mais sofisticada proposta metodológica para orientar processos de tomada de decisão que envolvem princípios em colisão, poderia desempenhar o papel esperado de uma estrutura de argumentação capaz de levar a respostas racionais. Confiar nos potenciais da proporcionalidade seria, assim, uma maneira de permitir algum grau de controle da subjetividade judicial, previsibilidade de resultados e distribuição ex ante de ônus de argumentação. E este parece ser o caso quando se encontra tantas referências entre autores do movimento civil constitucional à "ponderação de interesses" ou à "ponderação de valores" como norte para a justificação de decisões que erguem a pretensão de satisfazer as exigências de conformidade constitucional.

Neste ponto, ainda que a proporcionalidade seja amplamente evocada entre diferentes tribunais constitucionais ${ }^{57}$, sua aptidão para controlar racionalmente as valorações empreendidas por tomadores de decisão que recorrem a princípios é questionável. Por um lado, porque a incorporação do discurso dos princípios na prática forense brasileira costuma ser retratada como desorientada, fruto de oportunismo ou reflexo de um modismo. ${ }^{58}$ Como efeito desses traços, a proporcionalidade costuma se resumir a um topos argumentativo vazio, de apelo meramente retórico, já que raramente tribunais como o Supremo Tribunal Federal efetivamente realizam os três exames que

\footnotetext{
${ }^{55}$ Tepedino, O Direito Civil Constitucional e suas Perspectivas Atuais, p. 370.

${ }^{56}$ Esses mecanismos são também reconhecidos por Perlingieri. V. Perlingieri, Perfis do Direito Civil, p. 81.

${ }^{57}$ Stone-sweet, Proportionality, Balancing, and Global Constitutionalism, p. 75.

${ }^{58}$ V. ADPF no 101, fls. 209, no voto do ministro Eros Grau. Texto completo disponível em: $<$ http://redir.stf.jus.br/paginadorpub/paginador.jsp?docTP=AC\&doclD=629955>. Acesso em: $1^{\circ}$ out. 2014. Sundfeld, Princípio é Preguiça?, p. 60. Neves, Princípios e Regras: do juiz Hidra ao juiz lolau, p. $1149-1172$.
} 
estão por trás das etapas de adequação, necessidade e proporcionalidade em sentido estrito. ${ }^{59}$ Por outro lado, ainda que juízes e tribunais efetivamente buscassem satisfazer os ônus de argumentação exigidos pelo dever de proporcionalidade, há críticas estruturais que afirmam tanto déficits de racionalidade vinculados aos exames, como consideram delírios racionalistas as pretensões de Alexy de governar, por meio de um conhecimento profundo sobre a estrutura da ponderação, processos de tomada de decisão jurídica que envolvem a "ponderação" de princípios colidentes. ${ }^{60}$ Isso porque, no primeiro aspecto, seria a proporcionalidade incapaz de garantir níveis desejáveis de previsibilidade e objetividade dos resultados dos processos de solução de colisões de princípios, já que cada uma das suas etapas abriria espaço para elevadas margens de valoração. O caso mais notório da impossibilidade de controle da discricionariedade judicial estaria no plano da proporcionalidade em sentido estrito, nível em que se dá a realização dos princípios em colisão relativamente às possibilidades jurídicas. $\mathrm{Na}$ ponderação propriamente dita, só haveria decisionismo ${ }^{61}$ ou espaço para o desenvolvimento de juízos arbitrários ou irrefletidos. ${ }^{62}$ No segundo caso, por sua vez, os problemas da proporcionalidade se localizariam (i) em suas pretensões de reconstruir, à luz de referenciais normativos específicos, a prática do tribunal constitucional federal alemão de uma forma tal, que a tornaria um método de decisão excessivamente exigente do ponto de vista epistêmico, e (ii) na sua ambição de capturar, por meio de refinamentos metodológicos constantes (como o promovido pela fórmula do peso ${ }^{63}$ ), tão precisamente a estrutura do sopesamento a ponto de dissolver as diferenças estruturais entre ponderação e subsunção. ${ }^{64}$

Como se nota, objeções à ponderação de princípios podem ser levantadas em sentidos completamente opostos. Neste momento, porém, as duas grandes críticas formuladas contra a aplicação de princípios - a de um déficit e a de um excesso de racionalidade - não precisam ser detalhadas. Basta, ao contrário, mencioná-las para que se ateste que o discurso da ponderação de princípios não está livre de críticas contundentes, quase sempre negligenciadas por defensores da doutrina civil constitucional. Na mesma linha, ainda, seria possível erigir objeções semelhantes a métodos interpretativos construtivos que conjugam considerações axiológicas e sistemáticas. ${ }^{65}$ Se o movimento aposta em técnicas de justificação de decisões diferentes da subsunção, mas que tendem a aumentar a incerteza de processos jurídico-decisórios, investir em métodos de decisão capazes de garantir algum tipo de racionalidade aos

\footnotetext{
${ }^{59}$ V. Silva, O Proporcional e o Razoável, p. 31 e ss.

${ }^{60}$ Sobre essas críticas v. Leal, Racional ou Hiper-racional?.

${ }^{61}$ Schlink, Freiheit durch Eingriffsabwehr, p. 462.

${ }^{62}$ Habermas, Faktizität und Geltung, p. 316.

${ }^{63} \mathrm{~V}$. Alexy, Die Gewichtsformel.

${ }^{64}$ Sobre essas críticas v. com mais detalhes Leal, Irracional ou Hiper-racional? A Ponderação de Princípios entre o Ceticismo e o Otimismo Ingênuo, p. 186 e ss.

${ }^{65} \mathrm{~V}$. a respeito Aleixo, Verantwortbares Richterrecht, p. 227 e ss.
} 
juízos normativos singulares resultantes desse processo de abertura deveria, ao lado do desenvolvimento de uma dogmática segura, ser uma preocupação central dos seus seguidores.

\section{A Trivialização da Dignidade Humana}

Entre os conceitos básicos a partir dos quais o direito privado era explicado no século XIX, o de vontade desempenhava um papel fundamental para que a compreensão de institutos tradicionais de direito civil como propriedade e contrato se afastasse das bases jusnaturalistas predominantes nos séculos anteriores. $^{66}$ Se, por um lado, porém, a noção de vontade tornou-se, em substituição aos conceitos de justiça comutativa e distributiva, o conceito central em torno do qual o direito privado passou a ser construído no século que marca a era das grandes codificações ${ }^{67}$, por outro, críticos sublinhavam que nenhum outro conceito foi introduzido nas bases do direito privado capaz de limitar a que a vontade poderia legitimamente se dirigir. ${ }^{68} \mathrm{~A}$ noção de vontade era, segundo aqueles que criticavam a sua utilidade para cumprir o papel de unidade básica de compreensão do direito privado, soberana, mas, ao mesmo tempo, vazia a ponto de servir de fonte para explicar da maneira mais ampla e desparametrizada o que deveria ser considerado pelo direito como contrato ou como se conformariam juridicamente as regras que regiam a propriedade. Não é por outra razão que caricaturas sobre a utilidade efetiva do conceito de vontade eram feitas já na França no século XIX, como nesta irônica charada: "pergunta: o que o direito quer? Resposta: o que as partes querem. O que as partes querem? O que o direito quer!". ${ }^{69}$

O direito civil constitucional propõe inovação semelhante àquela causada pela introdução do conceito de vontade como base de compreensão do direito privado ao erigir a dignidade da pessoa humana à referência fundamental a partir da qual o direito civil deveria ser conformado ${ }^{70}$ e para cuja realização os institutos tradicionais de direito civil, especialmente aqueles relacionados a situações patrimoniais, deveriam ser funcionalizados. ${ }^{71}$ Considerada o centro do sistema constitucional, a dignidade humana se espraiaria por toda a ordem jurídica, condicionando a compreensão de todo o direito civil. É nesse aspecto que a dignidade cumpriria um papel importante para, por exemplo, determinar a interpretação extensiva de direitos da personalidade e, ao mesmo tempo, desfazer confusões conceituais como a que atribui à pessoa jurídica esses

\footnotetext{
${ }^{66}$ Gordley e von Mehren, An Introduction to the Comparative Study of Private Law, p. 63.

${ }^{67}$ Gordley, Foundations of Private Law, p. 7 e ss., especialmente p. 14. V. também, colocando o voluntarismo ao lado do individualismo como pilares fundamentais do Código de Napoleão e das codificações que nele se inspiraram, incluído o Código Civil de 1916, Tepedino, Premissas Metodológicas para a Constitucionalização do Direito Civil, p. 2.

${ }^{68}$ Gordley e von Mehren, An Introduction to the Comparative Study of Private Law, p. 63.

${ }^{69}$ Gordley e von Mehren, An Introduction to the Comparative Study of Private Law, p. 63. Tradução livre.

${ }^{70}$ Tepedino, O Direito Civil Constitucional e suas Perspectivas Atuais, p. 357. Moraes, A Caminho de um Direito Civil Constitucional, p. 6.

${ }^{71}$ Tepedino, O Direito Civil Constitucional e suas Perspectivas Atuais, p. 365.
} 
direitos $^{72}$, justificar a existência de limites à liberdade de contratar, inspirar uma nova leitura do regime de bens do Código Civil e possibilitar uma compreensão mais ampla de família. Mesmo em um contexto mais geral, como o de fundamentação e aplicação dos direitos humanos, a dignidade humana acabaria por exercer um papel fundamental ao atuar como uma espécie de "moeda geral" que possibilitaria diálogos judiciais transnacionais e empréstimos de soluções legais e institucionais entre diferentes jurisdições. ${ }^{33}$ Essas aplicações da dignidade seriam suficientes para questionar visões que tentam reduzir a dignidade a um valor moral desprovido de aplicabilidade jurídica. ${ }^{74}$

Especialmente problemático, porém, revela-se o incentivo fornecido pela doutrina civil constitucional para que juízes e advogados evoquem frequentemente a dignidade humana em processos de justificação de decisões. Isso ocorre porque a doutrina civil constitucional conjuga, como visto, um modelo particularista de tomada de decisão jurídica - sustentado pela necessidade de consideração de princípios incidentes em cada caso concreto - com a afirmação da primazia da dignidade e funcionalismo. Assim, parece natural crer que a busca pela melhor resposta constitucional para a solução de um problema específico tenha que passar pela dignidade humana e se localize exatamente na seleção da alternativa decisória que realiza no caso concreto, na maior medida possível, esse princípio. O que o direito civil constitucional acaba por estabelecer é, no fundo, uma pressão sobre tomadores de decisão por legitimação de suas decisões naquela que é considerada a norma mais importante do sistema constitucional. Neste ponto, a amplitude da expressão aliada às dificuldades de operacionalização adequada do princípio à luz de certas sugestões metodológicas propostas por autores do movimento (como o caráter imponderável da dignidade e a sua função de servir como norte da ponderação entre outros direitos fundamentais) tende a conferir à dignidade humana o mesmo papel vazio que se atribuía ao conceito de vontade no século XIX. Ela está em todo o lugar, mas não se sabe o que ela significa; ela serve para explicar tudo, mas é incapaz de orientar efetivamente processos de interpretação e aplicação do direito privado.

A dificuldade de se definir o que prescreve a dignidade humana não é uma novidade. Autores do movimento civil constitucional reconhecem que à expressão podem estar relacionados sentidos muito diversos. Maria Celina Bodin de Moraes, nesse sentido, afirma: "[u]ma vez que a noção é ampliada pelas numerosíssimas conotações que enseja, corre-se o risco da generalização, indicando-a como ratio jurídica de todo e qualquer direito fundamental. Levada ao extremo, essa postura hermenêutica acaba por atribuir ao princípio um grau de abstração tão intenso que torna impossível a sua aplicação". ${ }^{75}$ De fato, dadas a indeterminação semântica e a abertura estrutural do conceito,

\footnotetext{
${ }^{72}$ Nesse sentido, Tepedino, O Direito Civil Constitucional e suas Perspectivas Atuais, p. 365.

${ }^{73}$ Carozza, Human Dignity and Judicial Interpretation of Human Rights: a reply, p. 932.

${ }^{74}$ Sobre o tema v. Henry, The Jurisprudence of Dignity, p. 176.

${ }^{75}$ Moraes, Danos à Pessoa Humana, p. 84.
} 
não é possível dizer facilmente quando, do simples dever genérico de observar e proteger a dignidade da pessoa humana, direitos subjetivos dos titulares de dignidade são ou não assumidos. ${ }^{76}$ Tampouco é simples determinar o conteúdo desses direitos, ainda que a sua existência seja sustentável.

Lidar com essas e outras questões relacionadas ao manejo adequado da dignidade em casos concretos é um problema relacionado, sobretudo, ao conhecimento da sua estrutura. ${ }^{77}$ Mas essa não parece estar entre as preocupações centrais de acadêmicos e juristas práticos que incentivam o recurso frequente à dignidade. E, mesmo quando há algum tipo de esforço voltado a definir o sentido ou o modo de trabalho com a norma, o resultado proposto não costuma ser satisfatório. Um claro exemplo desse tipo de esforço pode ser localizado na proposta de Bodin de Moraes para lidar com as dificuldades de aplicação da dignidade. Para a autora, a construção de um conceito jurídico de dignidade depende da identificação do seu substrato material. Este, por sua vez, pode ser desdobrado em quatro postulados, que levariam à decomposição da dignidade em quatro sub-princípios: os da igualdade, da integridade física e moral, da liberdade e da solidariedade. ${ }^{78}$ Como solução geral, esse é um bom caminho para lidar com as dificuldades de operacionalização de princípios vagos. Em vez de se trabalhar com a norma mais geral, é sempre preferível trabalhar com os seus sub-princípios. Em primeiro lugar, porque é mais fácil identificar a direção das múltiplas razões que um princípio vago pode sustentar. Em segundo lugar, porque a superação das tensões entre princípios mais concretos em casos específicos pode ser orientada em métodos cuja estrutura é mais conhecida, como a proporcionalidade. A proposta de Bodin de Moraes, no entanto, peca por oferecer como critério de decisão para os casos de colisão entre corolários da dignidade a própria dignidade. Nas palavras da autora, "(...) embora possa haver conflitos entre duas ou mais situações jurídicas subjetivas, cada uma delas amparadas por um desses princípios, (...) o fiel da balança, a medida da ponderação, o objetivo a ser alcançado, já está determinado, a priori, em favor do princípio, hoje absoluto ${ }^{79}$, da dignidade humana". ${ }^{80}$ Há, como se nota, uma circularidade evidente na argumentação: para lidar com os problemas de aplicação de um princípio vago, recorre-se aos seus corolários para que, em casos de tensão, volte-se ao princípio vago para determinar o resultado da colisão.

Mas não só dificuldades de determinação da estrutura normativa da dignidade afetam a sua operacionalização. A identificação de um sentido preciso da norma parece também não ocupar as pautas daqueles que fomentam a aplicação da dignidade e decidem casos com base nela. Como já se disse,

\footnotetext{
${ }^{76}$ Teifke, Das Prinzip Menschenwürde, p. 68.

${ }_{77}^{77}$ Teifke, Das Prinzip Menschenwürde, p. 68.

${ }^{78}$ Moraes, Danos à Pessoa Humana, p. 85.

${ }^{79}$ Sobre a aptidão a ser ponderada da dignidade humana no âmbito da teoria dos princípios v. Teifke, Das Prinzip Menschenwürde, p. 155 e s.

${ }^{80}$ Moraes, Danos à Pessoa Humana, p. 85.
} 
"a popularidade crescente da dignidade não sinaliza algum acordo sobre o que o termo significa. Em vez disso, sua importância, significado e função são comumente pressupostos, mas raramente articulados." ${ }^{.11} \mathrm{O}$ que se costuma verificar na prática, na verdade, é uma tendência ao uso meramente retórico da norma. A evocação da dignidade vem quase sempre acompanhada da afirmação da sua importância ou de formulač̃es muito abertas, o que the garante o papel de mero topos argumentativo. ${ }^{82}$ Nesses casos, o efeito prático do recurso à dignidade é quase sempre o mesmo: o de obstrução do processo de fundamentação pela referência a algum conteúdo que, apesar do apelo geral, é, em casos específicos, apenas aparentemente consensual. Estar de acordo em abstrato com a necessidade de proteção da dignidade humana não leva diretamente, como anunciado, à determinação de que medida concreta deve ser adotada para preservá-la. Tampouco acordos gerais em torno de fórmulas genéricas como a versão do imperativo categórico que prescreve que o ser-humano deve ser tratado como um fim em si, não como um meio ${ }^{83}$, ou da amplíssima definição proposta por Sarlet ${ }^{84}$ são capazes de orientar, salvo em casos teratológicos, como o de escravidão, o que a proteção da dignidade efetivamente exige em um caso concreto. A fórmula kantiana, por exemplo, já foi, com razão, atacada por Schopenhauer por ser vaga, imprecisa, requerer, para cada caso de sua aplicação, prévia explicação, determinação e modificação especiais, e, em geral, ser insuficiente, dizer pouco e ser problemática. ${ }^{85}$

Definições muito abrangentes de dignidade, ainda que alcancem amplos acordos, tem utilidade normativa ou metodológica reduzida porque, não raro, a dignidade pode sustentar decisões opostas em um mesmo caso concreto. Isso porque a sua imprecisão semântica permite a extração de razões multidirecionais para sustentar pontos de vistas diversos. Como exemplo, basta citar que, no famoso HC 71.373-4/RS julgado pelo Supremo Tribunal Federal, a dignidade humana foi usada para justificar tanto a adequação constitucional de medida estatal que obrigava alguém a se submeter a exame de DNA em ação de investigação de paternidade como a sua inconstitucionalidade. ${ }^{86}$

\footnotetext{
${ }^{81}$ Henry, The Jurisprudence of Dignity, p. 172.

${ }^{82}$ Leal, Argumentando com o Sobreprincípio da Dignidade da Pessoa Humana, p. 51.

${ }^{83}$ Kant, Grundlegung zur Metaphysik der Sitten, p. 429.

${ }^{84}$ Para Sarlet, a dignidade da Pessoa humana é "a qualidade intrínseca e distintiva reconhecida em cada ser-humano que o faz merecedor do mesmo respeito e consideração por parte do Estado e da comunidade, implicando, neste sentido, um conjunto de direito e deveres fundamentais que assegurem a pessoa tanto contra todo e qualquer ato de cunho degradante e desumano, como venham a lhe garantir as condições existenciais mínimas para uma vida saudável, além de propiciar e promover sua participação ativa e co-responsável nos destinos da própria existência e da vida em comunhão com os demais seres humanos". Cf. Sarlet, As Dimensões da Dignidade da Pessoa Humana: construindo uma compreensão jurídico-constitucional necessária e possível, p. 37.

${ }^{85}$ Schopenhauer, Die Welt als Wille und Vorstellung, p. 714, par. 62. Trad. livre.

${ }^{86} \mathrm{O}$ ministro Marco Aurélio, por exemplo, afirma em seu voto: "[o]nde ficam a intangibilidade do corpo humano, a dignidade da pessoa, uma vez agasalhada a esdrúxula forma de proporcionar a uma das partes, em demanda civil, a feitura de uma certa prova?". Já o ministro Carlos Velloso,
} 
O potencial para produzir razões multidirecionais é, no fundo, uma característica típica de princípios constitucionais vagos. ${ }^{87}$ Assim, no processo de fundamentação de decisões, em vez de o recurso à dignidade garantir algum grau de racionalidade ao resultado, ele acaba, quando se restringe à simples menção da expressão, por atuar como obstáculo para o desenvolvimento de cadeias de razões. Isso se deve ao fato de a dignidade humana, como afirma Neumann, ter a força de encobrir, "sem exceção, de acordo com a opinião majoritária, todos os pontos de vista e argumentos que lhe sejam contrários, ali onde ela é atingida" ${ }^{88}$ Paradoxalmente, em vez de o comando vago facilitar a comunicação que deveria se estabelecer entre o juiz e os jurisdicionados do caso e os potencialmente afetados pela decisão, ele acaba atuando como um entrave. ${ }^{89}$

Mas os problemas decorrentes da pressão por legitimação de decisões a partir da dignidade em cada caso concreto incentivada pelo movimento civil constitucional não se resumem apenas à aplicação desorientada e ao uso retórico da expressão. Outro efeito perverso constatável é o de aplicação inflacionada da dignidade humana ${ }^{90}$ ou, em um sentido mais geral, de criação de um ambiente de "geleia geral" no direito brasileiro, no qual princípios vagos podem - e são usados para - justificar qualquer decisão. ${ }^{91}$ Neste ponto, o direito civil constitucional, ao propor um modelo de tomada de decisão judicial particularista e funcionalista, cria um contexto propício para que a dignidade humana apareça nos casos mais corriqueiros. ${ }^{92}$

A conjugação de uso retórico com aplicação inflacionada e desparametrizada traz como consequência mais grave a trivialização ou banalização da dignidade. A norma é frequentemente mencionada, mas sem que a sua invocação seja crucial ou, antes disso, que se saiba exatamente qual é o seu sentido ou como deve ser concretizada. Por conseguinte, o recurso à dignidade em uma decisão judicial tende a significar ou mera redundância, ou simples carência de fundamentação. A redundância ocorre

por sua vez, reconhece que, no caso, possui o filho "[...] ao que penso, o direito de conhecer o seu pai biológico. Esse direito se insere naquilo que a Constituição assegura à criança e ao adolescente: o direito à dignidade pessoal [...]". V. HC 71.373-4/ RS.

${ }^{87}$ Leal, Argumentando com o Sobreprincípio da Dignidade da Pessoa Humana, p. 49 e ss.

${ }^{88}$ Neumann, A Dignidade Humana como Fardo Humano - ou como utilizar um direito contra o seu respectivo titular, p. 226.

${ }^{89}$ Sobre essa relação paradoxal, v. Black, Forms and Paradoxes of Principles-based Regulation, p. 447-448.

${ }^{90}$ Neumann, A Dignidade Humana como Fardo Humano - ou como utilizar um direito contra o seu respectivo titular, p. 228.

${ }^{91}$ Sundfeld, Princípio é Preguiça?, p. 60. O autor se refere especificamente ao direito público, mas creio ser facilmente possível estender o alcance da constatação ao que ocorre em outras áreas. V. também Costa, Dignidade Humana: breves reflexões, p. 211.

${ }_{92} \mathrm{O}$ uso indiscriminado da dignidade humana também já se constatou na Alemanha, em que a dignidade humana também desempenha um papel central na ordem constitucional. Para Frankenberg, "[q]uanto mais exaltado seu valor, mais triviais os fins para os quais a dignidade é levada a campo". V. Frankenberg, Tyrannei der Würde? Paradoxien und Parodien eines Höchstwertes, p. 272. 
quando se constata a referência à dignidade em manifestações judiciais, mas se nota que o "trabalho" efetivo de justificação do juízo normativo singular é feito por regras e princípios mais concretos também citados na decisão. Nesses casos, a dignidade aparece como mero adorno e, como tal, dispensável. Já a carência de fundamentação se dá quando se constata o recurso exclusivo à dignidade no processo de fundamentação, mas sem a superação dos deveres de concretização exigidos para a demonstração de coerência entre o comando vago e a solução proposta. Nesta hipótese, a dignidade aparece como uma expressão sem valor. Mantidas essas práticas ao longo do tempo, a elevada dignidade acaba sendo rebaixada a uma "simples questão de bom gosto e dos bons costumes" ${ }^{\prime \prime 3}$. E, assim, a sua força normativa vai se esvaindo. ${ }^{94}$ Ao insistir prioritariamente na afirmação da centralidade da dignidade na ordem constitucional brasileira e na importância de realizá-la em casos concretos, mas sem dar passos consistentes capazes de torná-la uma ideia operativa ${ }^{95}$, o direito civil constitucional apenas aprofunda na realidade nacional um conjunto de problemas relacionados ao sentido, à estrutura e à aplicação da dignidade humana já identificados e vivenciados em outras ordens jurídicas.

\section{Excesso de Paternalismo Estatal}

A substituição da afirmação da vontade pela tutela da dignidade humana como centro de gravidade do direito privado desloca, em larga medida, o protagonismo do indivíduo para o Estado. É certo que a preservação da dignidade é um dever que se estende a atores privados. No entanto, concebida como o centro do sistema de direitos fundamentais da Constituição e dotada de um papel dúplice - já que à dignidade humana são atribuídos os papéis de limite e de programa normativo na ordem jurídica brasileira -, ela torna o Estado prioritariamente responsável pelo estabelecimento de estados de coisas marcados pela sua afirmação, reconhecimento, preservação e fomento. Papel de destaque tem, nesse processo, o Poder Judiciário, instituição sobre a qual recaem os ônus de busca pela conformidade constitucional em casos concretos que envolvam atuais ou potenciais restrições à dignidade em relações entre particulares ou entre estes e o Estado.

\footnotetext{
${ }^{93}$ Frankenberg, Tyrannei der Würde? Paradoxien und Parodien eines Höchstwertes, p. 274.

${ }^{94}$ Este é o reflexo de um problema mais geral relacionado ao privilégio conferido a princípios especialmente aos mais vagos - para nortear modelos de tomada de decisão. Julia Black, mesmo escrevendo especificamente sobre um modelo de regulação baseado em princípios, enuncia o que chama de "o paradoxo da supervisão e do enforcement". De acordo com esse paradoxo, os princípios precisam ser reforçados para que possam ter credibilidade, mas um excesso de enforcement pode levar ao seu esvaecimento. Este me parece ser exatamente o efeito mais perverso de um uso recorrente de princípios em diversos níveis na ordem jurídica brasileira. V. Black, Forms and Paradoxes of Principles-based Regulation, p. 450-452.

${ }^{95}$ A importância de tornar a dignidade humana uma categoria operativa no direito é destacada por Luís Roberto Barroso, quando afirma que "é preciso dotá-la de conteúdos mínimos, que deem unidade e objetividade à sua interpretação e aplicação. Do contrário, ela se transformaria em uma embalagem para qualquer produto, um mero artifício retórico, sujeito a manipulações diversas." V. Barroso, A Dignidade da Pessoa Humana no Direito Constitucional Contemporâneo - natureza jurídica, conteúdos mínimos e critérios de aplicação, p. 304.
} 
Um possível efeito perverso dessa mudança de referência é uma ampliação da incidência e do uso mais constante do princípio moral que justifica o exercício da coerção estatal para proteger o indivíduo de si mesmo ou, em uma versão mais forte, para guiá-lo na direção ao que é melhor para si, querendo ele ou não. ${ }^{96}$ Esta é uma formulação geral do que se possa chamar de paternalismo jurídico. Esse paternalismo se torna um efetivo perigo para o exercício da autonomia quando o Estado passa a se compreender como primordial guardião dos interesses individuais, atuando como se conhecesse as preferências dos seus cidadãos melhor do que eles mesmos. Esse risco, que produz uma espécie de repulsa a priori a regulações paternalistas, não é suficiente, contudo, para que se rejeite completamente qualquer tipo de paternalismo estatal. Como argumenta Feinberg, essa formulação parece justificável em alguns contextos morais, como nos casos de assunção de riscos com base em informação insuficiente ou de limitações epistêmicas ${ }^{97}$, e jurídicos, como nos casos de irrelevância do consentimento da vítima em casos de homicídio ou no reconhecimento da invalidade de um contrato que tem por objeto a obrigação de tornar-se escravo. ${ }^{98} \mathrm{Em}$ um exemplo menos radical, a possibilidade de se anular um negócio jurídico celebrado sob o defeito da lesão, prevista no artigo 157 do Código Civil, é uma maneira aparentemente razoável de o legislador evitar que o amplo exercício da liberdade - se é que é possível falar em real liberdade em casos de "premente necessidade" ou "inexperiência" - possa produzir resultados danosos ao indivíduo. Exemplos desse tipo revelam como uma forma fraca de paternalismo, de acordo com a qual o Estado tem o direito de prevenir condutas danosas dos indivíduos sobre si mesmo somente quando elas são substancialmente involuntárias ou quando uma intervenção temporária é necessária para que se possa aferir se tais condutas são voluntárias ou não, sugere a sua possível aceitação mesmo por árduos defensores da liberdade. ${ }^{99}$

\footnotetext{
${ }^{96}$ Assim, Feinberg, Legal Paternalism, p. 105 e Eidenmüller, Effizienz als Rechtsprinzip, p. 359 e 360.

${ }^{97}$ Feinberg, Legal Paternalism, p. 112-116, mas com alguns temperamentos.

${ }^{98}$ Feinberg, Legal Paternalism, p. 105. Para outros exemplos, Eidenmüller, Effizienz als Rechtsprinzip, p. $360-361$.

${ }^{99}$ A formulação é de Feinberg, Legal Paternalism, p. 113, citando expressamente John Stuart Mill como capaz de aceitar a anunciada versão fraca de paternalismo jurídico. Sobre outras estratégias de legitimação do paternalismo no direito v. Eidenmüller, Effizienz als Rechtsprinzip, p. 367-388. Porque o objetivo deste tópico não é legitimar medidas estatais paternalistas, mas, assumindo que o paternalismo existe e pode ser, em algum grau, justificável no direito, problematizar o seu alcance, há uma reconhecida simplificação na apresentação das questões que podem tornar o paternalismo no direito, como uma espécie de "aplicação" jurídica do paternalismo moral, mais ou menos defensável. Há questões sobre a legitimidade das decisões paternalistas de legisladores, o que comumente exige uma teoria democrática, problemas relacionados à pretensão de permanência das leis e os motivos que futuros legisladores podem ter para manter ou não a regulação paternalista, a dificuldade de se caracterizar certas medidas estatais como realmente paternalistas e ainda os efeitos perversos de tratar cidadãos como crianças ou mesmo, em alguns casos, deixar a democracia entregue a uma eterna infância. Sobre problemas desse tipo v. Husak, Legal Paternalism, p. 390 e ss.
} 
A justificativa, ainda que parcial, de alguns níveis de paternalismo não elimina, porém, a necessidade de fixação de (i) critérios materiais sobre a aceitabilidade de assunções voluntárias de riscos ou danos efetivos, (ii) presunções sobre o exercício consciente da vontade e (iii) regras de distribuição de ônus de prova capazes de definir os limites para a implementação de regulações paternalistas. ${ }^{100} \mathrm{E}$ é neste aspecto que, mais uma vez, o direito civil constitucional parece pecar, ao se limitar, de uma maneira geral, à simples afirmação de importância da dignidade e ao recurso a métodos muito abertos (como o recurso a interpretações sistemáticas) ou a estruturas formais de argumentação (como a proporcionalidade) para lidar com possíveis restrições à liberdade. O direito civil constitucional, se, por um lado, escancara as complexidades subjacentes aos problemas de legitimidade de escolhas individuais em uma ordem jurídica como a nossa, por outro, ao oferecer poucos critérios para lidar com essa complexidade, acaba por conceder amplíssimas margens de discricionariedade ao julgador. Assim, não é claro até que ponto o discurso civil constitucional pode evitar algum tipo de paternalismo judicial forte, que tende a asfixiar por completo a liberdade em nome da realização, em casos concretos, de subprincípios da dignidade, como a integridade psicofísica, a solidariedade e a igualdade, para citarmos apenas aqueles outros corolários identificados por Bodin de Moraes. ${ }^{101}$ Ao contrário, nada impede que juízes, em casos específicos, proíbam a assunção voluntária de risco devidamente informada ou mesmo a causação de danos intencionais que não causem prejuízos a terceiros em nome da necessidade de realização, na maior medida possível, da dignidade humana ${ }^{102}$ e de busca por uma leitura menos individualista do direito civil. Na mesma linha, nada também impede que, inspirados em concepções pessoais sobre dignidade humana que justificam como preferíveis certos estados de coisas, juízes imponham a atores privados certos cursos de ação. ${ }^{103}$ Os fundamentos para essa visão estão no tipo de conhecimento exigido pela doutrina civil constitucional para a aferição da juridicidade de condutas privadas e no papel atribuído ao Estado-juiz para manipular esse conhecimento. Uma teoria de tão complexa operacionalização acaba por conferir ao Estado o monopólio sobre o sentido do que está ou não conforme a dignidade ou, de uma maneira mais geral, conforme a Constituição.

\footnotetext{
${ }^{100}$ Para Husak, "attempts to evaluate instances of legal paternalism require, first, a set of principles about the value of different liberties; secondly, a theory about how given interferences affect the conditions under which persons are able to make their own lives; and, thirdly, some means to balance these (hopefully commensurable) values against one another." Husak, Legal Paternalism, p. 404.

${ }^{101}$ Moraes, Danos à Pessoa Humana, p. 85.

${ }^{102}$ V., por exemplo, o que Bodin de Moraes afirma sobre as colisões entre liberdade e solidariedade: "[n]ão se trata, portanto, de impor limites à liberdade individual, atribuindo maior relevância à solidariedade. O princípio a ser alcançado é o da dignidade da pessoa humana, o que faz com que a medida de ponderação para sua adequada tutela propenda ora para a liberdade, ora para a solidariedade." Moraes, Danos à Pessoa Humana, p. 108.

${ }^{103}$ Eidenmüller, Effizienz als Rechtsprinzip, p. 361. O autor se refere a esse tipo de paternalismo como paternalismo de valores (Wertepaternalismus).
} 
Independentemente das dificuldades metodológicas, o direito civil constitucional torna o conhecimento do que se deve ou não fazer um saber altamente especializado, pretensamente dominado por doutrinadores e tomadores de decisão, reveladores, em última análise, da vontade constitucional. No melhor cenário, pode-se dizer que as escolhas privadas são sempre provisórias, na medida em que estão permanentemente sujeitas ao crivo judicial.

O risco de paternalismo forte incentivado pelo movimento civil constitucional se torna mais evidente quando se nota que o seu discurso torna admissíveis restrições à liberdade não a partir de categorias tradicionais como ordem pública, interesse público ou interesse coletivo, todas elas problemáticas para funcionarem como óbices ao exercício de direitos ${ }^{104}$, mas tendo como base outros direitos fundamentais e, no limite, do direito fundamental mais importante: a dignidade humana. ${ }^{105}$ Neste ponto, o paternalismo estatal forte é apenas um reflexo possível da provocativa denúncia de uma "tirania da dignidade" feita por Frankenberg. ${ }^{106}$ Neste caso, uma tirania que pode ir minando ao longo do tempo a capacidade de indivíduos autônomos realizarem e agirem conforme as suas escolhas individuais.

\section{O Problema Institucional: afinal, as determinações legislativas vinculam?}

O tipo de particularismo incentivado pelo direito civil constitucional tende a criar um excesso de Constituição e a estabelecer uma onipotência judicial. Essa, porém, não é uma conclusão necessária. Não, pelo menos, do ponto de vista do desenho institucional. Se se entende que a busca por conformidade constitucional apenas reforça a possibilidade de controle concreto e difuso de constitucionalidade das leis, o direito civil constitucional não prescreve nada de excepcional. O problema, porém, pode estar no tipo de "controle obrigatório que o intérprete deve fazer da legitimidade constitucional de qualquer disposição, seja esta recente seja antiga, que seja aplicado ao caso concreto pelo juiz"107 sugerido pelo movimento. Se esse controle é compreendido como um dever positivo de busca da melhor solução constitucional para o caso - "mesmo em presença de aparentemente perfeita subsunção a uma norma"108 como a expressão de uma competência a ser exercida prioritariamente para a não aplicação de disposições legislativas inconstitucionais, é questionável como a teoria da interpretação jurídica proposta pela doutrina civil constitucional pode levar a sério a atividade legislativa. Dois aspectos contribuem para a afirmação dessa dificuldade. Primeiro, o direito civil constitucional atribui ao juiz o papel decisivo de, por meio da concretização de valores constitucionais,

\footnotetext{
${ }^{104}$ V. Dworkin, A Matter of Principle, p. 359 ("rights [...] are best understood as trumps over some background justification for political decisions that states a goal for the community as a whole") e Alexy, Individuelle Rechte und kollektive Güter.

${ }^{105}$ V. nessa linha Moraes, Danos à Pessoa Humana, p. 105.

${ }^{106}$ Frankenberg, Tyrannei der Würde? Paradoxien und Parodien eines Höchstwertes.

${ }^{107}$ Perlingieri, A Doutrina do Direito Civil na Legalidade Constitucional, p. 3.

${ }^{108}$ Moraes, A Caminho de um Direito Civil Constitucional, p. 11.
} 
determinar a resposta constitucionalmente adequada para cada caso concreto. Isso porque, como afirma Perlingieri, "[a] solução do problema concreto é procurada necessariamente na totalidade do ordenamento jurídico". ${ }^{109}$ Segundo, ele torna as disposições legislativas referências facilmente derrotáveis à luz de considerações constitucionais sustentadas por princípios. Protagonismo judicial e ausência de textualismo, sínteses dos dois aspectos problemáticos apontados, aliados ao particularismo decisório incentivado pelo movimento, à carência metodológica e à banalização da dignidade humana tendem a criar um contexto institucional em que o Legislador tem pouco espaço de atuação e no qual as suas decisões só são aplicadas quando convergem com uma análise global de fatos e normas constitucionais levados adiante pelo juiz em casos concretos.

Os perigos da onipresença constitucional e da onipotência judicial como efeitos de uma confiança excessiva nos direitos fundamentais e no seu reconhecimento como normas-princípio não são novos. Conceber princípios constitucionais como normas supremas da ordem jurídica e estimular a sua aplicação em cada caso conduziria, na conhecida crítica de Böckenförde à concepção de princípios como mandamentos de otimização e da visão de que direitos fundamentais possuem a estrutura de princípios, "a um modelo de Constituição com consequências fatais. O legislador parlamentar perderia toda a sua autonomia. Sua atividade esgotar-se-ia na mera constatação daquilo que já foi decidido pela Constituição. O processo político democrático perderia consideravelmente em importância e não seria mais possível deter a transição do Estado legislativo parlamentar para um Estado judiciário constitucional". ${ }^{110} \mathrm{Se}$, portanto, a busca por conformidade constitucional impuser ao juiz deveres tanto de anular as decisões legislativas que soem incompatíveis com a Constituição, como de desconsiderá-las, total ou parcialmente, ainda que sejam constitucionais, quando for possível construir diretamente da Constituição uma solução preferível para um caso concreto, corre-se o risco de mitigar a importância do Legislador. Isso porque, mais uma vez, as decisões legislativas, como as disposições do Código Civil, só são vinculantes quando exteriorizam o que o magistrado entende ser a melhor resposta constitucional para o problema.

Aparte a insuficiência metodológica para orientar a construção do que se possa entender por "melhor resposta constitucional", o possível desequilíbrio institucional promovido pela ampla aceitação do direito civil constitucional pode ser fruto de duas possíveis miopias. A primeira se localiza na crença de que tudo está na Constituição e que, por isso, o papel das instituições democráticas seria apenas o de descobrir o sentido das disposições

\footnotetext{
${ }^{109}$ Perlingieri, A Doutrina do Direito Civil na Legalidade Constitucional, p. 4. Grifo acrescido.

${ }^{110}$ V. Alexy, Teoria dos Direitos Fundamentais, p. 578. Esses e outros problemas relacionados à visão de direitos fundamentais como princípios jurídicos podem ser encontrados em Böckenförde, Grundrechte als Grundsatznormen.
} 
constitucionais, notadamente dos seus valores fundamentais. Nesta hipótese, o legislador praticamente não possui margens de conformação e o Judiciário se torna um controlador permanente da qualidade das decisões legislativas. Se elas convergem com o que possa ser a resposta constitucional adequada para o caso, podem ser aplicadas; se não, cabe ao juiz, que, assume-se, monopoliza um saber especializado que o coloca em condições melhores para conhecer e revelar o sentido da Constituição em cada problema pontual, substituí-las. A segunda possibilidade, por sua vez, reside no otimismo ingênuo sobre as capacidades judiciais para construir respostas tão boas ou melhores do que as legislativas para casos concretos, não só do ponto de vista da adequação constitucional das soluções propostas para problemas específicos, como também da possibilidade de promoção de virtudes dinâmicas do Estado de Direito, como previsibilidade, igualdade de tratamento de situações semelhantes, certeza e estabilidade. Nesta hipótese, assim como na anterior, o direito civil constitucional não fornece nenhuma evidência empírica em favor da suposta superioridade cognitiva dos juízes ou construção, normativa ou conceitual, a partir da qual sejam sustentáveis as referidas visões sobre a Constituição e a atividade jurisdicional em um regime democrático estruturado sobre a separação dos poderes. Em ambos os casos - ou em qualquer outra alternativa - é preciso que autores do movimento justifiquem como a ampla aceitação da pauta civil constitucional pode não conduzir a um Estado, ao mesmo tempo, judicial e superconstitucionalizado, em que disposições legislativas não parecem gozar de nenhum tipo de prioridade no processo de tomada de decisão jurídica.

Neste ponto, gostaria de explorar especificamente como a compreensão de autores do movimento - notadamente Perlingieri - sobre o papel das disposições jurídicas nos processos de formulação de juízos normativos singulares pode dificultar algum tipo de deferência ao trabalho legislativo. O ponto de partida do argumento é o de que as expressões textuais dos comandos legislativos precisam vincular, em alguma medida, a atividade judicial para que seja possível um regime de distribuição do poder político por meio de regras jurídicas. Essa desejável vinculação não leva necessariamente a um formalismo caricato, de acordo com o qual a aplicação de regras a determinados fatos se dá nos termos de uma inferência lógica. Este é um espantalho. ${ }^{111}$ Mas a rejeição dessa caricatura não afasta completamente a importância de algum grau de formalismo para o controle da discricionariedade judicial $^{112}$ e para o próprio funcionamento do direito ${ }^{113}$. Um formalismo não caricato, entendido como 0 ato de considerar as referências textuais

\footnotetext{
${ }^{111}$ Marmor, Interpretation and Legal Theory, p. 98.

112 Schauer, Balancing, Subsumption, and the Constraining Role of Legal Text, p. 312. Para Schauer, a questão central a respeito da argumentação jurídica diz respeito ao grau com que os materiais do direito (especialmente o texto das disposições legais) impõem limites aos julgamentos ilimitados e potencialmente variáveis de tomadores de decisão no âmbito do direito.

${ }^{113}$ Schauer, Thinking Like a Lawyer, p. 31.
} 
pretensamente autônomas em relação aos objetivos por elas buscados e, ao mesmo tempo, resistentes à consideração de outras razões incidentes em casos concretos ${ }^{114}$, revela-se importante não só porque promove virtudes caras do Estado de Direito, como porque a deferência a opções legislativas manifestadas em textos é um facilitador do controle democrático da atividade jurisdicional. Por esses motivos, faz sentido acreditar que a pergunta correta a ser respondida não é "formalismo - e, com ele, textualismo - ou não?", mas sim "qual grau de formalismo?". ${ }^{115}$

É questionável, porém, como o texto pode servir como razão suficiente para a tomada de decisão em certos casos em um modelo que não apenas estimula o particularismo como também concebe os processos de tomada de decisão jurídica como processos que sempre envolvem uma atividade construtiva. É certo que texto e norma não se confundem. Mas, para Perlingieri, "[a] clareza, na verdade, é uma eventual posterius, não um prius da interpretação". ${ }^{116}$ Disposições textuais são sempre o ponto de partida de um processo de interpretação. No entanto, a norma que se extrai para o caso concreto não precisa necessariamente ser um reflexo dos limites semânticos do texto potencialmente aplicável. Afinal, a norma para o caso concreto "deve estar em conformidade com os princípios e os valores do ordenamento e deve resultar de um procedimento argumentativo não somente lógico, mas axiologicamente de acordo com as escolhas de fundo do ordenamento". ${ }^{117}$ Assim, é perceptível por que a orientação normativa do direito civil constitucional é a de busca da solução adequada para o caso à luz da Constituição. ${ }^{118}$ Nesse quadro, os textos legislativos tendem a ter um papel secundário na decisão judicial, pois nada impede que eles se reduzam a apenas mais um elemento a ser considerado por aquele que precisa construir respostas jurídicas para casos específicos.

A chave para sustentar a rejeição a qualquer prioridade ao texto no processo de formação do conteúdo normativo está em uma teoria hermenêutica que parte da impossibilidade de as palavras possuírem algum tipo de significado que não dependa da consideração de relações entre o objeto que se quer designar por meio delas e a experiência. Esta parece ser a inspiração hermenêutica da pauta civil constitucional. Para Perlingieri "não existe (...) um sentido imanente à palavra, este é a relação (e nada mais) entre o texto e um

\footnotetext{
${ }^{114}$ Schauer, Formalism. Alexander, Comigo é Tudo ou Nada, p. 166. Sunstein, Must Formalism be Defended Empirically?, p. 638-640.

${ }^{115}$ Sunstein, Must Formalism be Defended Empirically?, p. 640.

${ }^{116}$ Perlingieri, A Doutrina do Direito Civil na Legalidade Constitucional, p. 3. Perlingieri, Perfis do Direito Civil, p. 71.

${ }_{117}$ Perlingieri, A Doutrina do Direito Civil na Legalidade Constitucional, p. 3.

${ }^{118}$ Para Perlingieri, mais uma vez, "o controle de conformidade da lei à Constituição é uma constante de qualquer interpretação para fins aplicativos, de qualquer aplicação que procure individualizar, em uma quaestio facti, em um caso concreto, a solução que não poderá não ser coerente, adequada e razoável e então correspondente à tábua dos valores normativamente relevantes, presentes na Constituição". Perlingieri, A Doutrina do Direito Civil na Legalidade Constitucional, p. 3-4.
} 
objeto ao qual se refere". ${ }^{119}$ Interpretar é, para o autor, uma necessidade permanente para a individuação da resposta adequada para o caso, que é necessariamente a que se mostra "mais compatível com os interesses e valores em jogo". ${ }^{120}$ Isso porque as palavras não podem ser consideradas compreensíveis sem que se leve em conta as referências necessariamente externas, como "um contexto material ou um contexto de experiência", que lhe dão significado efetivo. ${ }^{121} \mathrm{E}$, no direito, defende o autor que os referenciais para a identificação desses contextos estão nos valores fundamentais que garantem a unidade e o sentido do ordenamento. Interpretar é, por isso, uma tarefa de construção de sentidos imersa na sistemática do texto e na axiologia da ordem jurídica, e não uma atividade focada exclusivamente em identificar o sentido de disposições textuais.

Avaliar criticamente essa concepção hermenêutica exige um retorno ao tema dos casos difíceis. Mas, desta vez, não como uma questão pragmática relacionada aos efeitos atrelados ao amplo endosso do direito civil constitucional, tal qual explorada anteriormente. Neste ponto, é preciso discutir se a existência de casos claros que possam decorrer da simples compreensão das formulações textuais de comandos legislativos - expressões de casos fáceis - é uma possibilidade conceitual. O raciocínio é simples: se casos claros não são possíveis, o holismo permanente sugerido pelo direito civil constitucional pode ser mais facilmente justificado, mesmo em um regime democrático amparado na separação de poderes. Para Perlingieri, essa visão parece fazer sentido. Não porque casos claros não sejam possíveis. Mas porque a clareza não decorre de algum tipo de entendimento não mediado do sentido de textos, e sim da estabilização de interpretações sobre as palavras que o compõem. ${ }^{122}$ Para o autor a clareza não é uma qualidade das palavras. Ela é, na verdade, o produto de uma relação entre texto, valores e realidade que se deixa conhecer após o processo de interpretação. Nessa linha, não é surpreendente que Perlingieri rejeite o brocardo in claris non fit interpretatio e afirme que "[o] intérprete não pode limitar-se a levar em consideração a fórmula legislativa, mas deve investigar a ratio iuris". ${ }^{123}$

Mas seria realmente indefensável a visão de que as referências textuais não podem ser suficientes para a observância de uma regra sem que, para tanto, seja necessária qualquer interpretação? ${ }^{124}$ Parece-me que não.

\footnotetext{
${ }^{119}$ Perlingieri, Perfis do Direito Civil, p. 68.

${ }^{120}$ Perlingieri, Perfis do Direito Civil, p. 72.

${ }^{121}$ Perlingieri, Perfis do Direito Civil, p. 68-69.

122 Sobre os problemas dessa visão v. Leal, Comments on Susanna Pozzolo's 'Easy Case and Legal Routine', p. 216-218.

${ }_{123}$ Perlingieri, A Doutrina do Direito Civil na Legalidade Constitucional, p. 71-72.

${ }^{124}$ A disputa sobre a existência de casos claros no direito, como tantas outras discussões já apresentadas ao longo deste texto, não é recente. Esta é uma questão que está no centro, por exemplo, do famoso debate Hart-Fuller. V. Hart. Positivism and the Separation of Law and Morals, p. 593-629 e Fuller. Positivism and Fidelity to Law: A Reply to Professor Hart, p. 630-672. V. também sobre a existência ou não de casos claros no direito Pozzolo, Easy Case and Legal
} 
A defesa de uma resposta negativa para aquela questão parte da possibilidade de se sustentar que, ainda que se aceite que as palavras sejam potencialmente indeterminadas, existem exemplos paradigmáticos que mostram acordos sobre a sua aplicação em diversos casos. ${ }^{125}$ Sustentar essa visão não parece ser uma tarefa tão complicada. Ordinariamente recorremos a exemplos considerados claros para definir o sentido de certos conceitos, ainda que possamos admitir diferenças entre os objetos por eles designados. Assim, ainda que haja diferenças substantivas entre xadrez, futebol e paciência, não há dúvidas relevantes entre falantes da língua portuguesa que os três são espécies de "jogos". ${ }^{126} \mathrm{E}$ isso independentemente de qualquer atividade interpretativa. Ao contrário. Quando alguém, sob circunstâncias normais, não reconhece ou questiona a aplicabilidade da palavra "jogo" a esses casos ou a quaisquer outros considerados exemplos-padrão, dizemos que esta pessoa não domina o uso do conceito. ${ }^{127} \mathrm{E}$, por mais que seja possível atribuir a conceitos patologias como a textura aberta da linguagem e a eles relacionar a derrotabilidade como característica insuperável, esses não parecem ser traços que sejam capazes de eliminar a existência de amplos acordos sobre a aplicabilidade clara de conceitos e, para o que é central nesta objeção, das regras que deles se servem para a formulação de suas prescrições em algumas situações.

Ao contrário do que parece supor Perlingieri, compreender o que exige uma disposição legislativa não depende necessariamente de algum esforço interpretativo. Desvincular "compreender" de "interpretar" é importante para se sustentar a possibilidade de haver fidelidade ao direito apenas com base no que as regras, por meio das suas palavras, dizem - e esta é a chave para que as disposições legislativas sejam capazes de vincular e, dessa forma, limitar a atividade judicial. No limite, entender que compreender não depende necessariamente de interpretar é o que permite reconhecer quando alguém está, de fato, seguindo uma regra.

Não há, por um lado, divergência entre o que se afirma neste ponto e o que Perlingieri sugere quando defende que o significado de palavras e regras estão relacionados a algum contexto. Mas isso não significa dizer, por outro, que identificar o sentido das prescrições formuladas por meio de regras e aplicá-las em casos concretos depende da consideração de valores, sejam eles os propósitos buscados pelas regras ou qualquer outro estado de coisas considerado juridicamente relevante, como se eles pavimentassem uma ponte entre a regra e o curso de ação a ser adotado em um caso. ${ }^{128} \mathrm{~A}$ observância

Routine, p. 195-213; Leal, Comments on Susanna Pozzolo's ‘Easy case and legal routine', p. 214-219; Pozzolo, About Fernando Leal's Commentary, p. 220-221 e Stone, Focalizando o Direito: o que a interpretação jurídica não é, p. 47-143. V. ainda Aleixo, Verantwortbares Richterrecht, p. 121 e ss.

${ }^{125}$ Sobre esta interpretação do que Hart pretende quando diferencia casos centrais de casos de penumbra relacionados a conceitos, v. Marmor, Interpretation and Legal Theory, p. 102.

${ }^{126} \mathrm{O}$ exemplo é de Marmor. Cf. Interpretation and Legal Theory, p. 102.

127 Marmor, Interpretation and Legal Theory, p. 103.

128 Sobre essa visão, com explícita inspiração em Wittgenstein, v. Marmor, Interpretation and Legal Theory, p. 114-115. 
da práxis é relevante porque "o sentido das regras é determinado pelas próprias ações, ou seja, pelo modo como as regras são aplicadas". ${ }^{129}$ Compreender uma regra significa, portanto, ser capaz de determinar as ações que estão com ela de acordo, o que não significa interpretar, mas simplesmente transparecer o que significa obedecer ou não a uma regra. ${ }^{130}$ Regras e palavras precisam ser capazes de se referir a casos e ações independentemente da evocação de outros elementos. Voltando ao direito civil constitucional, acreditar que uma interpretação constitucional é sempre necessária para que se defina a aplicação de uma regra, por exemplo, do Código Civil, é uma maneira de simplesmente reconhecer que, no fundo, juízes sempre criam novas regras. Isso porque, se uma regra não é capaz de determinar quais ações estão com ela de acordo, tampouco uma interpretação pode fazê-lo. A consequência do endosso dessa visão é simples: há sempre criação de padrões de comportamento em cada caso. Como afirma Marmor, "[a] interpretação é só uma outra formulação da regra, por meio da qual uma formulação [a legislativa] é substituída por outra [a judicial], como se aquela fosse."131 Neste contexto, mesmo que se admita que os casos claros são o produto das interpretações, e não governados por relações semânticas, a atividade judicial permanece no centro, pois é ela que deve lidar com a indeterminação radical do direito assumida pelo direito civil constitucional. ${ }^{132}$ Nesses termos, permanece questionável o quanto o direito civil constitucional é capaz de fornecer uma teoria da interpretação e uma teoria normativa da decisão jurídica compatíveis com algum grau de vinculação a decisões legislativas.

\section{A Expansão dos Limites do Direito: por que separar o raciocínio jurídico do raciocínio moral?}

A valorização da dignidade humana, a busca constante por conformidade constitucional e a proposta de uma leitura moral da Constituição formulada por alguns autores do movimento ${ }^{133}$ tendem a diluir as fronteiras entre 0 jurídico e o moral. Em uma outra imagem, o direito civil constitucional cria condições para uma inundação do direito por padrões de moralidade, sejam eles oriundos da amplitude do conceito de dignidade e da concepção que vincula a tarefa do direito à sua máxima proteção, sejam eles decorrentes do particularismo preocupado com as melhores respostas para casos específicos. O efeito mais drástico dessa inundação é o de corrosão completa do lado formal do direito.

A sobreposição produzida não só afeta os critérios para a identificação do direito válido, como também os processos de tomada de decisão jurídica

\footnotetext{
${ }^{129}$ Marmor, Interpretation and Legal Theory, p. 115. Grifo no original. V. também Stone, Focalizando o Direito: o que a interpretação jurídica não é, p. 71 e ss.

${ }_{130}$ Marmor, Interpretation and Legal Theory, p. 115.

${ }^{131}$ Marmor, Interpretation and Legal Theory, p. 114.

${ }^{132}$ Sobre a relação entre necessidade permanente de interpretação e indeterminação global do direito v. Stone, Focalizando o Direito: o que a interpretação jurídica não é.

${ }^{133}$ Perlingieri, A Doutrina do Direito Civil na Legalidade Constitucional, p. 9.
} 
de uma maneira particular. O tipo de vinculação entre direito e moral sugerido pela doutrina civil constitucional, que contribui para o aumento de casos difíceis, prescreve a funcionalização das situações patrimoniais à tutela de opções existenciais e investe em uma teoria decisória ao mesmo tempo particularista, anti-formalista e metodologicamente desparametrizada, na medida em que precisa confiar em um trabalho dogmático ${ }^{134}$ que, até o momento, não se pode assumir ser suficiente para controlar as incertezas dos processos de tomada de decisão judicial, impede a diferenciação entre raciocínio jurídico e o raciocínio prático. No mundo civil constitucional, tomar decisões jurídicas não parece ser diferente de tomar decisões morais, pois o correto parece gozar de prioridade absoluta sobre o formal. Além disso, neste mundo, todos os dilemas morais se tornam problemas jurídicos. ${ }^{135}$ No limite, basta para tanto simplesmente relacionar a qualquer situação concreta uma restrição ou a possibilidade de promoção da dignidade humana. Em resumo: tudo o que é moral é juridicamente relevante e a maneira adequada de lidar com essas questões é raciocinar moralmente. Ambas as consequências colocam em xeque, em um nível mais elevado, o papel do próprio direito na realidade social ou, sob uma certa perspectiva, os seus próprios méritos morais.

Para construir o meu argumento, parto de duas teses. Ambas são controvertidas, mas, apresentadas da forma mais branda possível, podem ser, a meu ver, consideradas pouco problemáticas. A primeira é a de que o direito realiza alguns objetivos socialmente importantes. $E$ isso independentemente do reconhecimento de que o direito está necessariamente a serviço de certos fins. A segunda é a de que a existência do direito se justifica por algumas deficiências da moralidade. $\mathrm{E}$ isso independentemente do endosso de alguma

\footnotetext{
${ }^{134}$ A construção de uma dogmática adequada à proposta civil constitucional é uma das preocupações centrais do movimento. V. Tepedino, O Direito Civil Constitucional e suas Perspectivas Atuais, p. 371.

${ }^{135}$ Não me parece evidente, nesse sentido, que problemas como os de abandono afetivo ou de cabimento de danos morais por rompimento de namoro ou noivado sejam, em si, problemas propriamente jurídicos, ainda que sejam problemas morais. No que diz respeito ao abandono afetivo, há entendimento do STJ no seguinte sentido: "[c]omo escapa ao arbítrio do Judiciário obrigar alguém a amar, ou a manter um relacionamento afetivo, nenhuma finalidade positiva seria alcançada com a indenização pleiteada. Nesse contexto, inexistindo a possibilidade de reparação a que alude o art. 159 do Código Civil de 1916, não há como reconhecer o abandono afetivo como dano passível de indenização". V. Resp. 757.411/MG, p. 9. No mesmo sentido, o Tribunal de Justiça de Minas Gerais entendeu que "[o] abandono afetivo do pai em relação ao filho não enseja o direito à indenização por dano moral, eis que não há no ordenamento jurídico obrigação legal de amar ou de dedicar amor. Logo, não há responsabilidade civil, pretérita ou atual, do pai em relação ao filho, face à ausência de conduta ilícita ou antijurídica daquele". V. Apelação Cível $n^{\circ}$ 1.0702.03.056438-0/001 - MG. Quanto à possibilidade de ocorrência de dano moral em decorrência de rompimento de noivado, o STJ entendeu: "[n]ão há, portanto, comprovação nos autos de que o autor ou sua filha tenham sido submetidos a um comportamento abusivo do réu capaz de corroborar a compensação indenizatória pleiteada na exordial, já que a situação gerada por uma desilusão amorosa, por si só, é insuficiente para ensejar a responsabilidade civil, como bem restou salientado na sentença". V. Ag. Resp. 249.898/MG, p. 2 e 3. Sobre o tema, o Tribunal de Justiça do Paraná atestou que "[a] simples ruptura de noivado não legitima só por isso a pretensão indenizatória, se não vislumbrada ilicitude no rompimento". V. Apelação Cível nº 1426280/PR.
} 
teoria específica sobre a natureza do direito - i.e. sem que seja necessário subscrever uma teoria positivista ou não positivista. A partir dessas duas teses, pretendo justificar, ao contrário do que o direito civil constitucional leva a crer, por que o direito só é social e, sobretudo, moralmente justificável se for possível separar, ainda que esta seja uma questão de grau, tanto o que é jurídico do que é moral como o raciocínio jurídico do raciocínio moral.

Em relação à primeira tese, é discutível se o direito como um todo está necessariamente a serviço de certos fins. Kelsen, por exemplo, concebe o direito apenas como um meio específico ${ }^{136}$. Dworkin, por sua vez, estipula que o ponto ou propósito da prática jurídica é justificar o exercício da coerção estatal. ${ }^{137}$ Shapiro, por fim, vincula à atividade jurídica o propósito fundamental de remediar as deficiências morais do que chama de "circunstâncias da juridicidade". ${ }^{138}$ Essas disputas profundas sobre se a natureza do direito está relacionada a fins e sobre quais seriam esses fins, que envolvem considerações sobre os próprios projetos metodológicos de autores que se propõem a oferecer teorias sobre a natureza do direito, não impedem, porém, que se reconheça que o direito inegavelmente realiza certas coisas. Como diz Green, fazendo referência a Hart, o direito, por exemplo, "regula a conduta humana por meio de regras". ${ }^{139}$ Esse é um fato que pode ser reconhecido para além de disputas sobre se "regular comportamentos" é um objetivo a que certas práticas sociais deveriam necessariamente aspirar ou necessariamente realizar para que possam ser caracterizadas como direito. Da mesma forma, nada impede que se reconheça que, ao guiar comportamentos ou dissolver desacordos morais particulares, o direito acaba produzindo estados de coisas que podem ser classificados como moralmente valiosos, ainda que não se defenda, mais uma vez, que a busca pela realização desses objetivos não é o que define conceitualmente o direito. Reconhecer que o direito pode realizar estados de coisas que podem ser valorados moralmente chega a ser trivial a ponto de não ser objeto de discussão relevante entre positivistas e não positivistas. ${ }^{140} \mathrm{O}$ ponto nevrálgico da discussão neste momento, porém, é

\footnotetext{
${ }^{136}$ Kelsen, Reine Rechtslehre, 1. ed., p. 32.

${ }^{137}$ Dworkin, Law's Empire, p. 93.

${ }^{138}$ Esta é chamada de "moral aim thesis". V. Shapiro, Legality, p. 213. Os problemas por trás das circunstâncias da juridicidade envolvem basicamente os custos e os riscos relacionados ao desenvolvimento de planos diferentes do direito - considerado como um grande plano pelo autor - para lidar com problemas morais numerosos, importantes e de solução complexa. Porque outras alternativas não conseguem lidar eficientemente com essas circunstâncias é que o direito se desenvolve como grande mecanismo de planejamento social para lidar com questões morais complexas.

${ }^{139}$ Green, Law as a Means, p. 2.

${ }^{140}$ Sobre este ponto arumenta Raz: "For example, it is a conceptual point about the law that it can be morally evaluated as good or bad, and as just or unjust, just as it is a conceptual fact about black holes that propositions like 'this black hole is morally better or more just than that' make no sense. So there are conceptually necessary connections between law and morality which no legal positivist has any reason to deny." Cf. Raz, The Argument from Injustice, or how not to Reply to Legal Positivism, p. 21.
} 
saber como ou por quais meios o direito produz estados de coisas moralmente valiosos. É neste aspecto que a diluição do lado formal do direito estimulada em alguma medida pelo direito civil constitucional torna-se um alvo para objeções contundentes.

Parece inquestionável no atual nível de sofisticação a que os debates sobre a natureza do direito chegaram que traços formais e institucionais desempenham um papel central para diferenciar o direito e o raciocínio jurídico da moral e do raciocínio prático em geral. Se esta é uma tese amplamente difundida entre positivistas ${ }^{141}$, ela também pode ser encontrada em não positivistas como Dworkin ${ }^{142}$ e Alexy $^{143}$, na medida em que ambos também concebem diferenças entre processos de tomada de decisão jurídica e processos de tomada de decisão no âmbito da moral, como a necessidade de se levar a sério (i) regras como razões para a ação que atuam sobre o comportamento individual de uma maneira diferente do modo como atuam razões morais ${ }^{144}$ ou (ii) outros aspectos formais e institucionais que limitam ou impedem a busca pelas melhores respostas possíveis para questões práticas específicas. Assim, independentemente de disputas sobre o caráter necessário da vinculação entre direito e finalidades e sobre o conteúdo desses propósitos, se o direito realiza estados de coisas moralmente relevantes, é porque existem certos traços típicos do direito que o diferenciam da moral. E entre esses traços estão características formais, como levar a sério regras escritas e o raciocínio por subsunção. ${ }^{145}$

Justificar por que, do ponto de vista moral, faz sentido diferenciar os pontos de vista jurídico e moral nos leva à segunda tese anteriormente anunciada. De acordo com ela, a existência do direito e o seu funcionamento peculiar dos processos jurídicos de solução de questões práticas é algo moralmente valioso. Com outras palavras, se há motivos para se levar a sério o lado formal do direito, que se expressa, por exemplo, na consideração da autonomia do texto das regras, na assunção do caráter autoritativo de precedentes e na força vinculante de procedimentos, eles não decorrem de versões caricatas de formalismos e positivismos, mas podem ser reconduzidos a argumentos morais. E aqui, mais uma vez, em larga medida para além das disputas entre positivistas e não positivistas. Para Shapiro, representante do positivismo exclusivo, como anunciado, a adoção do direito como um abrangente

\footnotetext{
${ }^{141}$ V., por exemplo, Hart, The Concept of Law, p. 249; Schauer, Balancing, Subsumption, and the Constraining Role of Legal Text, p. 315-316; Alexander, "Comigo é Tudo ou Nada". Formalismo no Direito e na Moralidade, passim; Raz, Incorporation by Law, p. 187, 192 e Raz, Reasoning with Rules, p. 204-205.

${ }^{142} \mathrm{Em}$ favor dessa visão, Schauer, Balancing, Subsumption, and the Constraining Role of Legal Text, p. 315.

${ }_{143}$ Alexy, Theorie der Juristischen Argumentation e Alexy, Hauptelemente einer Theorie der Doppelnatur des Rechts.

${ }^{144}$ Nessa linha, afirma Raz que "[m]orality, unlike the law or the norms governing the university or any other social institution, is not a system of rules". Raz, Incorporation by Law, p. 184.

${ }^{145}$ Schauer, Balancing, Subsumption, and the Constraining Role of Legal Text, p. 316.
} 
mecanismo de planejamento é indispensável para resolver os problemas de custo e de coordenação que a moralidade não consegue eliminar. ${ }^{146}$ Para o autor, a simples possibilidade de tornar critérios de validade de normas jurídicas dependentes de elementos morais já impede que regras jurídicas possam garantir algum tipo de conformidade com as suas prescrições de uma maneira que afete o processo de tomada de decisões práticas dos seus destinatários capaz de diferenciá-lo do raciocínio prático geral. ${ }^{147}$ Para Alexy, por sua vez, a positividade do direito também é uma necessidade para lidar com deficiências da busca por correção em um ambiente não ideal e sem instituições jurídicas. Afinal, nada garante, em um mundo governado apenas pela busca por correção, (i) que uma única reposta para problemas práticos será encontrada - e, ainda que sua existência seja possível, que ela possa ser conhecida -, (ii) que as respostas morais, uma vez encontradas, serão observadas e (iii) que haverá a organização social necessária para que objetivos morais valiosos sejam realizados. ${ }^{148}$ Por isso, segundo o autor, a necessidade das instituições jurídicas e da positividade do direito decorre de exigências morais de se evitar os custos da anarquia e da guerra civil e de se alcançar as vantagens da coordenação e da cooperação sociais. ${ }^{149}$ É a relevância da segurança social em um mundo subideal que justifica uma prioridade prima facie da dimensão de segurança jurídica frente à dimensão de justiça, que só é invertida quando, por exemplo, o reconhecimento da validade de certas normas ou a sua aplicação produzir injustiças extremas. ${ }^{150}$ Mas a realização de propósitos moral e socialmente importantes só é possível quando se leva a sério o lado formal do direito. Nessas bases, tanto na visão de Alexy como de Shapiro, (i) conceber regras legisladas e precedentes como razões fortes para a tomada de decisão, (ii) criar limites para que a inadequação moral seja razão suficiente para a declaração de invalidade de normas promulgadas em consonância com os procedimentos estabelecidos para a criação de obrigações jurídicas e postas por autoridades determinadas como responsáveis por dizer o que o direito é em certa ordem jurídica e (iii) reconhecer a subsunção como um tipo de raciocínio tipicamente jurídico são cruciais para que o direito seja funcionalmente relevante para a realização de objetivos moral e socialmente desejáveis em um mundo dotado de características que tornam sem sentido a busca permanente pelas melhores respostas em cada problema prático.

\footnotetext{
${ }^{146}$ Na mesma linha, Alexander, "Comigo é Tudo ou Nada". Formalismo no Direito e na Moralidade, p. 184-185. Para o autor "[o] direito, na forma de regras formais, é uma solução para o problema dos limites do conhecimento moral" (p. 184).

${ }^{147}$ Shapiro, Law, Morality, and the Guidance of Conduct.

${ }^{148}$ Alexy, Hauptelemente einer Theorie der Doppelnatur des Rechts, p. 158. Alexander, em linha próxima, afirma que o acordo vinculante para lidar com problemas morais possibilitado pelo direito resolve problemas de coordenação, expertise e eficiência. V. "Comigo é Tudo ou Nada". Formalismo no Direito e na Moralidade, p. 16 e ss..

${ }^{149}$ Alexy, The Dual Nature of Law, p. 173.

${ }^{150}$ Alexy, Hauptelemente einer Theorie der Doppelnatur des Rechts, p. 159.
} 
Como se percebe, em ambos os casos a justificação moral da própria existência do direito exige que os processos de solução de problemas se desenvolvam de maneiras diferentes nos planos jurídico e moral. E a aptidão do direito para realizar objetivos moralmente relevantes depende dessa diferenciação. Assumir, portanto, que os pontos de vista jurídico e moral não precisam coincidir não pressupõe que a moralidade esteja sendo descartada. Ao contrário, há boas razões que justificam por que a moral consegue acomodar o direito e, assim, se se parte da ideia de que ela sempre está potencialmente presente na solução de questões práticas, excluir-se, mesmo que parcialmente, dos processos de tomada de decisão jurídica. Se se pode assumir que as determinações do direito são consideradas normativamente válidas e vinculantes, não é, portanto, porque elas retiram a sua legitimidade do próprio direito. Como diz Raz, o direito não dá autoridade à moral. É a moral que dá autoridade ao direito. ${ }^{151}$ Não há, assim, nada que conceitualmente nos impeça de observar esse conjunto de normas que impõem obrigações a que chamamos de "direito", mesmo quando essas disposições levem a resultados concretos subótimos do ponto de vista moral em nome de virtudes morais. Tentar, portanto, aproximar direito e moral, raciocínio jurídico e raciocínio prático, a ponto de apagar as fronteiras que os diferenciam - como parece sugerir o direito civil constitucional -, pode ter inspirações nobres, como a busca pelas melhores respostas para problemas práticos a partir da consideração de toda a riqueza dos detalhes de cada caso. Entretanto, não se pode esquecer, esse mesmo caminho pode significar deixar de lado muito do que torna o direito social e moralmente atraente.

\section{CONCLUSÃO: FUNCIONALISMO OU INSTRUMENTALISMO?}

O direito civil constitucional, como inicialmente anunciado, é sem dúvida um dos movimentos de maior êxito na trajetória jurídica brasileira inaugurada pela Constituição federal de 1988. Isso se explica, ao menos em parte, não só pelas bandeiras cativantes que, no geral, levam a consensos quase que imediatos em seu favor - a rejeição a um formalismo caricato e o compromisso com a realização de direitos fundamentais são apenas dois simples exemplos nesse sentido -, como pela real necessidade, vivenciada, sobretudo, após os primeiros anos de vigência da atual Constituição, de harmonização de algumas disposições do Código Civil e de alguns institutos clássicos da disciplina às prescrições constitucionais e à dogmática - em especial à dogmática dos direitos fundamentais - que se construiu nos últimos anos no país.

As nobres pretensões da teoria, contudo, não impedem a localização de problemas em suas bases. Neste trabalho, tentei desenvolver seis pontos que, a meu ver, podem dificultar a aceitação tão rápida de uma perspectiva específica, tal qual proposta pelo movimento civil constitucional, para compreender e enfrentar problemas privados e as normas que os afetam. No fundo, todos os

\footnotetext{
${ }^{151}$ Raz, Incorporation by Law, p. 189-190.
} 
seis pontos convergem para corroer aquela que parece ser a principal revolução teórica pregada pelo discurso de busca por conformidade constitucional: a funcionalização de todo o direito civil, incluídos neste pacote os seus institutos tradicionais, as regras que o conformam e os processos de solução de problemas dessa natureza, para a realização da dignidade humana na solução do maior número possível de problemas jurídicos.

Ao contrário do que se poderia pensar, porém, as críticas levantadas não pretendem necessariamente atacar esse objetivo. Elas tentam, na verdade, apenas apontar os aspectos das construções teóricas do direito civil constitucional que tendem a transformá-lo em uma teoria instrumentalista do direito civil. Este é um perigo que ronda constantemente teorias normativas da tomada de decisão jurídica orientadas na realização de objetivos. Em sua versão mais extremada, a orientação do processo de justificação de decisões jurídicas na realização de objetivos conduz a um modelo decisório que conjuga um consequencialismo de primeira ordem com um ceticismo de regras. ${ }^{152}$ Nesse contexto, o material jurídico pretensamente autoritativo não é capaz de vincular tomadores de decisão. Ele é, na verdade, livremente manipulado para sustentar juízos normativos singulares que, no fundo, decorrem das preferências individuais daqueles a quem se atribui competência para construir, com os olhos voltados para o alcance de fins muito amplos, a resposta constitucionalmente adequada para cada caso concreto. Reduzido a um simples meio para a implementação de fins, o direito não é mais do que "an empty vessel without builty-in restraints". ${ }^{153}$ A desfuncionalização do direito é, nesses termos, o produto de um modelo decisório orientado na realização de objetivos vagos, na necessidade de consideração de muitos elementos normativos (incluindo os compromissos menos densos da Constituição), na ausência de qualquer prioridade em favor de regras legislativas, na carência de critérios e métodos operacionalizáveis capazes de limitar as opções decisórias e no particularismo. ${ }^{154}$ Não por acaso, essas são as principais objeções que consegui formular ao direito civil constitucional a partir da filosofia constitucional e da teoria do direito. Superá-las, e evitar, assim, que o amplo endosso do direito civil constitucional leve a um colapso instrumentalista, parece ser uma tarefa ainda não completamente realizada pelos defensores do movimento. Não, pelo menos, se o direito civil constitucional for compreendido apenas como uma teoria normativa da decisão judicial que pode ser diretamente aplicada, nos termos apresentados, para a solução de casos concretos. Mas, se não for isso, e o direito civil constitucional limitar as suas pretensões normativas à reorientação de esforços doutrinários de construção de parâmetros para a tomada da decisão jurídica em compromissos constitucionais, avanços são necessários para que, naquilo em que pode ser

\footnotetext{
152 Sobre essa caracterização de instrumentalismo v. Leal, Ziele und Autorität, p. 273.

153 Tamanaha, Law as a Means to an End, p. 273.

${ }^{154}$ Leal, Ziele und Autorität, p. 274 e ss.
} 
decisivo para o estabelecimento de uma nova maneira de se pensar o direito civil, o movimento não fique estacionado no "ponto zero" da dogmática jurídica. ${ }^{155}$

\section{REFERÊNCIAS}

ALEIXO, Pedro Scherer de Mello. Verantwortbares Richterrecht. Eine rechtstheoretische und methodenkritische Untersuchung. Tübingen: Mohr Siebeck, 2014.

ALEXANDER, Larry. "Comigo é Tudo ou Nada": formalismo no direito e na moralidade. In: RODRIGUEZ, José Rodrigo (Org.). A Justificação do Formalismo Jurídico: textos em debate. São Paulo: Saraiva, p. 165-200, 2011,

ALEXY, Robert. Die Gewichtsformel. In: JICKELI, J.; KREUTZ, P.; REUTER, D. (Org.). Gedächtnisschrift für Jürgen Sonnenschein. Berlin: De Gruyter Recht, p. 771-779, 2003.

. Hauptelemente einer Theorie der Doppelnatur des Rechts. ARSP, v. 95, $\mathrm{n}^{\circ} 2$, p. 151-166, abr. 2009.

. Individuelle Rechte und kollektive Güter. In: . Recht, Vernunft, Diskurs. Frankfurt am Main: Suhrkamp, p. 232-261, 1995.

. Teoria dos Direitos Fundamentais. Trad. Virgílio Afonso da Silva. São Paulo: Malheiros, 2008.

. The Dual Nature of Law. Ratio Juris, v. 23, no 2, p. 167-182, jun. 2010.

. Theorie der Grundrechte. Frankfurt a.M.: Suhrkamp, 2006.

Theorie der Juristischen Argumentation. 2. ed., Frankfurt a.M.: Suhrkamp, 1991.

. On Balancing and Subsumption. A Structural Comparison. Ratio Juris, v. 16, no 4, p. 433-449, dez. 2003.

ÁVILA, Humberto. Neoconstitucionalismo: entre a ciência do direito e o direito da ciência. Revista Eletrônica de Direito do Estado, Salvador, no 17, p. 1-19, 2009. Disponível em: <http://www.direitodoestado.com/revista/rede-17-janeiro-2009-humberto\%20avila.pdf>. Acesso em: 01 out. 2014.

Teoria dos Princípios. Da Definição à Aplicação dos Princípios Jurídicos. 10. ed., São Paulo: Malheiros, 2009.

BARCELLOS, Ana Paula de. Ponderação, Racionalidade e Atividade Jurisdicional. Rio de Janeiro: Renovar, 2005.

BARROSO, Luís Roberto. A Doutrina Brasileira da Efetividade. In: . Temas de Direito Constitucional. Rio de Janeiro: Renovar, p. 61-79, 2005.

. Neoconstitucionalismo e Constitucionalização do Direito (o triunfo tardio do direito constitucional no Brasil). Disponível em: <http://www.luisrobertobarroso.com.br/wpcontent/themes/LRB/pdf/neoconstitucionalismo_e_constitucionalizacao_do_direito_pt.pdf $>$. Acesso em: 04 ago. 2015.

. A Dignidade da Pessoa Humana no Direito Constitucional Contemporâneo Natureza Jurídica, Conteúdos Mínimos e Critérios de Aplicação. In: O Novo Direito Constitucional Brasileiro. $2^{\mathrm{a}}$ reimpressão, Belo Horizonte: Fórum, p. 285-329, 2013.

\footnotetext{
${ }^{155} \mathrm{O}$ mesmo tipo de crítica é formulado por Jestaedt para se referir à insuficiência dos complexos instrumentos metodológicos desenvolvidos pela teoria dos princípios para, sem trabalho dogmático complementar, que ela possa cumprir as suas promessas de conduzir processos decisórios concretos e, assim, garantir algum tipo de controle da discricionariedade judicial. V. Jestaedt, Die Abwägungslehre - ihre Stärken und ihre Schwächen, p. 268-269.
} 
BLACK, Julia. Forms and Paradoxes of Principles-based Regulation. Capitol Markets Law Journal, v. 3, n 4, p. 425-457, Oxford University Press, set. 2008.

BÖCKENFÖRDE, Ernst-Wolfgang. Grundrechte als Grundsatznormen. Zur gegenwärtigen Lage der Grundrechtsdogmatik. In:

Frankfurt a.M.: Suhrkamp, p. 189-229, 2006.

Wissenschaft, Politik, Verfassungsgericht.

CAROZZA, Paolo G. Human Dignity and Judicial Interpretation of Human Rights: a reply. The European Journal of International Law, v. 19, nº 5, p. 931-944, 2008.

COSTA, Helena Regina Lobo da. Dignidade Humana: breves reflexões. In: PASCHOAL, Janaina Conceição; SILVEIRA, Renato de Mello Jorge (Org.). Livro Homenagem a Miguel Reale Júnior. 1. ed., Rio de Janeiro: LMJ Mundo Jurídico, p. 207-218, 2014.

DWORKIN, Ronald. A Matter of Principle. Cambridge: Harvard University Press, 1986. . Law's Empire. 8. ed., Cambridge: Harvard University Press, 1993.

EIDENMÜLLER, Horst. Effizienz als Rechtsprinzip. 3. ed., Tübingen: Mohr Siebeck, 2005.

FACHIN, Luiz Edson. A Reforma no Direito Brasileiro: novas notas sobre um velho debate no direito civil. In: FACHIN, Luiz Edson; TEPEDINO, Gustavo (Org.). Obrigações e Contratos - obrigações: estrutura e dogmática. São Paulo: Revista dos Tribunais, p. 229-236, 2001, (coleção doutrinas essenciais, v. 1).

FEINBERG, Joel. Legal Paternalism, Canadian Journal of Philosophy, v. 1, $\mathrm{n}^{\circ} 1$, p. 105-124, set. 1971.

FRANKENBERG, Günter. Tyrannei der Würde? Paradoxien und Parodien eines Höchstwertes. In: do mesmo autor (Org.). Autorität und Integration. Suhrkamp, p. 270-282, 2003.

FULLER, Lon L. Positivism and Fidelity to Law: A Reply to Professor Hart, Harvard Law Review 71, p. 630-672, 1958.

GORDLEY, James; MEHREN, Arthur Taylon Von. An Introduction to the Comparative Study of Private Law: readings, cases, materials. New York: Cambridge University Press, 2006.

GORDLEY, James. Foundations of Private Law. Property, Tort, Contract, Unjust Enrichment. New York: Oxford University Press, 2006.

GREEN, Leslie. Law as a Means. In: CANE, Peter (Ed.). The Hart-Fuller Debate in the Twenty-First Century. Oxford and Portland: Hart, 2010. Disponível em: <http://ssrn. com/abstract=1351304>. Acesso em: 05 ago. 2015.

HABERMAS, Jürgen. Faktizität und Geltung. 4. ed., Frankfurt a.M.: Suhrkamp, 1994.

HART, H.L.A. The Concept of Law. Oxford [u.a.]: Oxford University Press, 1961.

. Positivism and the Separation of Law and Morals. Harvard Law Review,

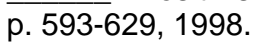

HENRY, Leslie Meltzer. The Jurisprudence of Dignity. University of Pennsylvania Law Review, v. 160, set. 2011. Disponível em: <http://ssrn.com/abstract=1928768>. Acesso em: 05 ago. 2015.

HESSE, Konrad. A Força Normativa da Constituição. Trad. Gilmar Mendes. Porto Alegre: Sérgio Antônio Fabris, 1991.

HUSAK, Douglas N. Legal Paternalism. In: LaFOLLETTE, Hugh (Org.). The Oxford Handbook of Practical Ethics. New York [u.a.]: Oxford University Press, p. 387-412, 2003. 
JESTAEDT, Matthias. Die Abwägungslehre - ihre Stärken und ihre Schwächen. In: Otto Depenheuer et al. (Org.). Staat im Wort. Festschrift für Josef Isensee. Heidelberg: C. F. Müller, p. 253-275, 2007.

KANT, Immanuel. Grundlegung zur Metaphysik der Sitten. Sttutgart: Philipp Reclam, 2008. KELSEN, Hans. Reine Rechtslehre. 1. ed., Tübingen: Mohr Siebeck, 1934.

LEAL, Fernando. Argumentando com o Sobreprincípio da Dignidade da Pessoa Humana. Arquivos de Direitos Humanos, v. 7, p. 41-67, 2007.

. Comments on Susanna Pozzolo's 'Easy case and legal routine'. Revista

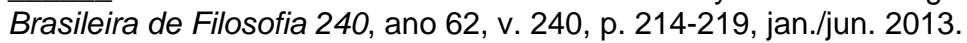

. Irracional ou Hiper-racional? A ponderação de princípios entre o ceticismo e o otimismo ingênuo. A\&C - Revista de Direito Administrativo e Constitucional, Belo Horizonte, ano 14, no 58, p. 177-209, out./dez. 2014.

. Todos os Casos jurídicos são Difíceis? Sobre as Relações entre Efetividade, Estabilidade e Teorias da Decisão Constitucional. Revista de Direito do Estado, 16, p. 87-116, 2009.

. Ziele und Autorität. Baden-Baden: Nomos, 2014.

LÔBO, Paulo. Novas Perspectivas da Constitucionalização do Direito Civil. Revista Jus Navigandi, Teresina, ano 18, $\mathrm{n}^{\circ} 3754,11$ out. 2013. Disponível em: <http://jus.com.br/ artigos/25361/novas-perspectivas-da-constitucionalizacao-do-direito-civil>. Acesso em: 04 ago. 2015.

MARMOR, Andrei. Interpretation and Legal Theory. 2. ed., Oxford e Portland: Hart, 2005. MORAES, Maria Celina Bodin de. A Caminho de um Direito Civil Constitucional. Texto disponível em: http://empreendimentosjuridicos.com.br/site/wp-content/uploads/2015/06/ CaminhosDireitoCivilConstitucional-Maria-Celina-B-Moraes.pdf. Acesso em: 01 set. 2015.

Danos à Pessoa Humana: uma leitura civil constitucional dos danos morais. Rio de Janeiro: Renovar, 2003.

. O Princípio da Dignidade Humana. In: Contemporâneo. Rio de Janeiro: Renovar, p. 1-60, 2006.

(Org.), Princípios do Direito Civil

NEUMANN, Ulfried. A Dignidade Humana como Fardo Humano - ou como utilizar um direito contra o seu respectivo titular. In: SARLET, Ingo Wolfgang (Org.). Dimensões da Dignidade. Ensaios de Filosofia do Direito e Direito Constitucional. 2. ed., Porto Alegre: Livraria do Advogado, p. 225-240, 2009.

NEVES, Marcelo. Princípios e Regras: do juiz Hidra ao juiz Iolau. In: COSTA, José Augusto F.; ANDRADE, José Maria Arruda; MATSUO, Alexandra Mery H. (Orgs.). Direito: teoria e experiência. Estudos em homenagem a Eros Roberto Grau. São Paulo: Malheiros, t. II, p. 1149-1172, 2013.

PERLINGIERI, Pietro. A Doutrina do Direito Civil na Legalidade Constitucional. In: TEPEDINO, Gustavo (Org). Direito Civil Contemporâneo. Novos Problemas à Luz da Legalidade Constitucional: Anais do Congresso Internacional de Direito Civil Constitucional da Cidade do Rio de Janeiro. São Paulo: Atlas, p. 1-11, 2008.

. Perfis do Direito Civil: introdução ao direito civil constitucional. Trad. Maria

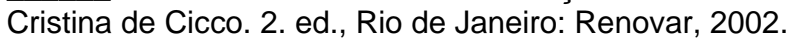

POZZOLO, Suzanna. Easy Case and Legal Routine. Revista Brasileira de Filosofia 240, ano 62, v. 240, p. 195-213, jan./jun. 2013. 
. About Fernando Leal's Commentary. Revista Brasileira de Filosofia, ano 62, v. 240, p. 220-221, jan./jun. 2013.

RAZ, Joseph. The Argument from Injustice, or How not to Reply to Legal Positivism. In: PAVAKLOS, George (Org.). Law, Rights and Discourse. The Legal Philosophy of Robert Alexy. Oxford: Hart, p. 17-35, 2007.

. Incorporation by Law. In:

. Between Authority and Interpretation.

New York [u.a.]: Oxford University Press, p. 182-202, 2009.

. Reasoning with Rules. In:

. Between Authority and Interpretation.

New York [u.a.]:Oxford University Press, p. 203-219, 2009.

SARMENTO, Daniel. Direitos Fundamentais e Relações Privadas. Rio de Janeiro: Lumen Juris, 2004.

SCHAUER, Frederick. Balancing, Subsumption and the Constraining Role of Legal Text. In: KLATT, Matthias (Org.). Institutionalized Reason: the jurisprudence of Robert Alexy. New York [u.a.]: Oxford University Press, p. 307-318, 2012.

. Formalism. The Yale Law Journal, v. 97, nº 4, p. 509-548, mar. 1988.

. Playing by the Rules: a philosophical examination of rule-based decisionmaking in law and life. Oxford: Clarendon Press, 1991.

. Thinking Like a Lawyer. Cambridge: Harvard University Press, 2009.

SANCHÍS, Luis Prieto. Neoconstitucionalismo y Ponderación Judicial. In: CARBONELL, Miguel (Org.). Neoconstitucionalisamo(s). Madrid: Editorial Trotta, p. 123-158, 2003.

SARLET, Ingo Wolfgang. As Dimensões da Dignidade da Pessoa Humana: construindo uma compreensão jurídico-constitucional necessária e possível. In: . (Org.)

Dimensões da Dignidade. Ensaios de Filosofia do Direito e Direito Constitucional. 2. ed., Porto Alegre: Livraria do Advogado, p. 15-43, 2009.

SCHLINK, Bernhard. Freiheit durch Eingriffsabwehr - Rekonstruktion der klassischen Grundrechtsfunktion. Europäische Grundrechte Zeitschrift, p. 457-468, 1984.

SCHOPENHAUER, Arthur. Die Welt als Wille und Vorstellung. 1. ed., Leipzig: Brodhaud, 1844.

SHAPIRO, Scott J. Law, Morality, and the Guidance of Conduct. Legal Theory, v. 6, $\mathrm{n}^{\circ} 2$, p. 127-170, jun. 2000.

. Legality. Cambridge: The Belknap Press of Harvard University Press, 2011.

SILVA, Virgílio Afonso da. O Proporcional e o Razoável. Revista dos Tribunais, v. 798, p. 23-50, 2002.

A Constitucionalização do Direito. Os Direitos Fundamentais nas Relações entre Particulares. São Paulo: Malheiros, 2005.

STONE-SWEET, Alec; MATHEWS, Jud. Proportionality Balancing and Global Constitutionalism. Faculty and Affiliate Scholarship Series, Paper 14, 2008. Disponível em: <http://digitalcommons.law.yale.edu/fss_papers/14/>. Acesso em: 01 out. 2014.

STONE, Martin. Focalizando o Direito: o que a interpretação jurídica não é. In: MARMOR, Andrei (Org.). Direito e Interpretação. Trad. Luís Carlos Borges. São Paulo: Martins Fontes, p. 47-143, 2004.

SUNDFELD, Carlos Ari. Princípio é Preguiça?. In: Direito Administrativo para Céticos. São Paulo: Direito FGV/Malheiros, p. 60-84, 2012. 
SUNSTEIN, Cass R. Must Formalism be Defended Empirically?. The Univeristy of Chicago Law Review, v. 66, nº 3, p. 636-670, summer 1999.

TAMANAHA, Brian Z. Law as a Means to an End: threat to the rule of law. New York: Cambridge University Press, 2006.

TEIFKE, Nils. Das Prinzip Menschenwürde. Zur Abwägungsfähigkeit des Höchstrangigen. Tübingen: Mohr Siebeck, 2011.

TEPEDINO, Gustavo. O Direito Civil Constitucional e suas Perspectivas Atuais. In: . (Org.). Direito Civil Contemporâneo. Novos Problemas à Luz da Legalidade

Constitucional: Anais do Congresso Internacional de Direito Civil Constitucional da Cidade do Rio de Janeiro. São Paulo: Atlas, p. 356-371, 2008.

- Premissas Metodológicas para a Constitucionalização do Direito Civil. In: . Temas de Direito Civil. Rio de Janeiro: Renovar, p. 1-22, 2004. 